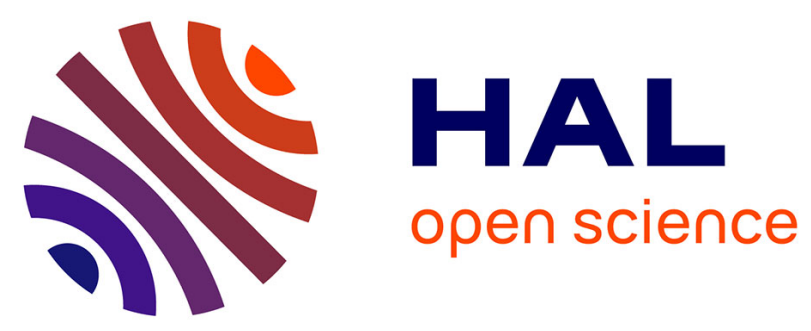

\title{
Relationships between magmatism and extension along the Autun-La Serre fault system in the Variscan Belt of the eastern French Massif Central
}

\author{
Flavien Choulet, Michel Faure, Olivier Fabbri, Patrick Monié
}

\section{- To cite this version:}

Flavien Choulet, Michel Faure, Olivier Fabbri, Patrick Monié. Relationships between magmatism and extension along the Autun-La Serre fault system in the Variscan Belt of the eastern French Massif Central. International Journal of Earth Sciences, 2012, 101 (2), pp.393-413. 10.1007/s00531-0110673-z . insu-00596918

\section{HAL Id: insu-00596918 https://hal-insu.archives-ouvertes.fr/insu-00596918}

Submitted on 10 Jun 2011

HAL is a multi-disciplinary open access archive for the deposit and dissemination of scientific research documents, whether they are published or not. The documents may come from teaching and research institutions in France or abroad, or from public or private research centers.
L'archive ouverte pluridisciplinaire HAL, est destinée au dépôt et à la diffusion de documents scientifiques de niveau recherche, publiés ou non, émanant des établissements d'enseignement et de recherche français ou étrangers, des laboratoires publics ou privés. 
1 Relationships between magmatism and extension along the Autun - La Serre fault system in

2 the Variscan Belt of the eastern French Massif Central

$5 \quad$ Flavien Choulet $^{1, *}$, Michel Faure ${ }^{1}$, Olivier Fabbri ${ }^{2}$, Patrick Monié ${ }^{3}$

$6{ }^{1}$ ISTO, UMR 6113 - CNRS/Université d'Orléans, 1A, rue de la Férollerie, 45071 Orléans

7 Cedex 2, France

$8{ }^{2}$ Chrono-environnement, UMR 6249 - Université de Franche-Comté, 16, route de Gray 925030 Besançon Cedex, France

$10{ }^{3}$ Géosciences Montpellier, UMR CNRS 5243, Université Montpellier II, Place Bataillon, 1134095 Montpellier Cedex 5, France

12 Corresponding author

13 flavien.choulet@univ-orleans.fr, +33238492573

Abstract

The ENE-WSW Autun Shear Zone, in the northeastern part of the French Massif Central has been interpreted previously as a dextral wrench fault. New field observations and microstructural analyses document a NE-SW stretching lineation that indicates normal dextral motions along this shear zone. Further east, similar structures are observed along the La Serre Shear Zone. In both areas, a strain gradient from leucogranites with a weak preferred 21 orientation to highly sheared mylonites supports a continuous Autun-La Serre fault system.

22 Microstructural observations and shape and lattice preferred orientation document hightemperature deformation and magmatic fabrics in the Autun and La Serre granites, whereas

24 low- to intermediate-temperature fabrics characterize the mylonitic granite. Electron 25 microprobe monazite geochronology of the Autun and La Serre granites yields a ca. $320 \mathrm{Ma}$ 
age for pluton emplacement, while mica ${ }^{40} \mathrm{Ar}-{ }^{39} \mathrm{Ar}$ datings of the Autun granite yield plateau ages from 305 to $300 \mathrm{Ma}$. The ca. $300 \mathrm{Ma}{ }^{40} \mathrm{Ar}-{ }^{39} \mathrm{Ar}$ ages, obtained on micas from Autun and La Serre mylonites, indicate the time of the mylonitization. The ca. 15 Ma time gap between pluton emplacement and deformation along the Autun-La Serre fault system argue against a synkinematic pluton emplacement during late-orogenic to post-orogenic extension of the Variscan Belt. A ductile to brittle continuum of deformation is observed along the shear zone, with Lower Permian brittle faults controlling the development of sedimentary basins. These results suggest a two-stage Late Carboniferous extension in the northeastern French Massif Central, with regional crustal melting and emplacement of the Autun and La Serre leucogranites around $320 \mathrm{Ma}$, followed, at 305-295 Ma, by ductile shearing, normal brittle faulting, and subsequent exhumation along the Autun -La Serre transtensional fault system.

Keywords: Variscan Belt, Late Carboniferous shear zones, synkinematic granite, ${ }^{40} \mathrm{Ar}-{ }^{39} \mathrm{Ar}$ dating, electron microprobe monazite dating, quartz c-axis, French Massif Central.

\section{Introduction}

Continental collision leads to the thrusting of two lithospheric plates and a subsequent crustal thickening during orogen formation. Once the lithostatic and compressional strengths are no longer balanced, the orogen becomes unstable and collapses (e.g. Malavieille 1987; Dewey 1988). The gravitational collapse of the thickened crust is accommodated by extension and is characterized by thermal relaxation inducing partial melting of the continental crust (England and Thompson 1986). S-type magmatism, granite-gneiss domes and normal shear zones document syn to post-orogenic extension (Reynolds and Spencer 1985; McClay et al. 1986; Norton 1986). 
51 Paleozoic orogen interpreted as the result of the collision between Laurussia, Gondwana, and several intermediate microcontinents such as Armorica or Avalonia (Matte 1986; 2001; Franke 1989). In the French Massif central, one of the main pieces of the Variscan orogen, successive phases of nappe stacking in Devonian and Early Carboniferous times (Burg and

Matte 1978; Ledru et al. 1989) led to an important thickening of the crust, and were followed by an important episode of crustal melting (Duthou et al. 1984). During the Late Carboniferous, the collapse of the Variscan Belt (Ménard and Molnar 1988; Burg et al. 1994; Faure 1995) generated normal brittle faults (Echtler and Malavieille 1990; Faure and BecqGiraudon 1993), normal ductile shear zones (Mattauer et al. 1988; Malavieille et al. 1990), synkinematic granitoids (Faure and Pons 1991; Talbot et al. 2004; Joly et al. 2009), and granite-gneiss domes (Ledru et al. 2001). Although the timing of these events is relatively well established (Faure 1995), the connection between magmatism and extensional tectonics is not always clear. A common idea is that most of the plutons are synkinematic bodies emplaced along normal or strike-slip faults (Faure and Pons 1991; Faure 1995).

This study deals with extensional structures documented by field observations, microstructural analysis, and geochronology of granitoids and mylonites. We focus on the Morvan and La Serre horsts in the northeastern part of the French Massif Central, where Stype granites, ductile shear zones, and syn-sedimentary faults are exposed. We propose an interpretation of the late orogenic to post-orogenic evolution of this segment of the Variscan Belt. We shall use the classical chronostratigraphic stages of Western Europe for the Late Paleozoic period, with Namurian corresponding to Late Mississipian - Early Pennsylvanian (326-313 Ma), Westphalian to Middle Pennsylvanian (313-307 Ma), Stephanian to Late Pennsylvanian (307-303 Ma), Autunian to Late Pennsylvanian - Middle Cisuralian (303-276 Ma), and Saxonian to Late Cisuralian - Middle Guadalupian (276-263 Ma) (Ogg et al. 2008). 
2. Geological outline

Two types of scenario have been proposed to account for the geodynamical evolution of the Variscan Belt of Western Europe. The first type is monocyclic and is based on a continuous Paleozoic convergence between Gondwana and Laurussia (Matte 1991; Lardeaux et al. 2001). Alternatively, a polycyclic evolution with two successive orogenic episodes was proposed (Pin 1990; Faure et al. 1997). The reliability of the two scenarios is extensively discussed in several papers (e.g. Faure et al. 2005) and will not be addressed here. In this contribution, the polycyclic scenario is retained. In this model, the first cycle resulted from the Silurian north-directed subduction of the ocean that separated Gondwana and Armorica. al., 2001), crustal nappes were stacked towards the SW, then partly migmatized, and finally exhumed during the Devonian around 390-380 Ma (Floc'h 1983; Quenardel and Rolin 1984; Roig and Faure 2000; Faure et al. 2008). The second cycle was related to the closure of the the Devonian Brévenne ophiolite (Leloix et al. 1999) are interpreted as remnants of a magmatic arc and a back-arc basin related to the southward subduction of the Rheic Ocean (Faure et al. 1997). north. Late Visean magmatic series, locally called "Tufs Anthracifères", postdate the midCarboniferous events (Faure et al. 2002). The Late orogenic stage is characterized by two 
100 Namurian to Westphalian NW-SE extension characterized by leucogranite emplacement

101 (Faure and Pons 1991), followed by a Stephanian to Permian NE-SW extension characterized

102 by brittle normal faulting and formation of coal-bearing half-grabens (Arthaud and Matte

103 1977; Echtler and Malavieille 1990; Malavieille et al. 1990). Whatever the geodynamic

104 scenario (monocyclic or polycyclic), the Late Carboniferous syn-orogenic to post-orogenic

105 extension is widely accepted,.

106

107

2.2. The northeastern French Massif Central

108

The study area is located in the northeastern French Massif Central, also called

Morvan area, which forms a horst between the Cenozoic Limagne and Bresse grabens (Fig.

110 1). Paleozoic metamorphic units are unconformably overlain by Devonian to Early

111 Carboniferous sedimentary and magmatic rocks (Delfour 1989; Faure et al. 1997) and are

crosscut by Carboniferous magmatic intrusions with varied geochemical characteristics (Rolin and Stussi 1991). The last manifestation of this magmatic event is the emplacement of

114 peraluminous plutons such as the Autun granite (Chévremont et al. 1999; Fig. 2a), located 115 close to ductile shear zones in the Autun and Avallon areas (Rolin and Stussi, 1991). Late

116 orogenic brittle wrench or normal faults controlled the development of the Stephanian to 117 Permian coal-bearing half-grabens or pull-apart basins such as the Autun, Epinac or Le 118 Creusot basins (Marteau 1983; Vallé et al. 1988; Fig. 1). These intramontane basins are 119 characterized by a terrigeneous sedimentation, which started during the Late Stephanian and 120 remained active during the Permian (Courel 2001). Stephanian to Permian high-K acidic 121 volcanism is also reported (Carpena et al. 1987; Chévremont et al. 1999). East of the Oligocene Bresse graben, and close to the northern end of the Jura foldand-thrust belt, the La Serre horst displays structures similar to those of the Autun area (Fig. 
124 3), with a leucogranitic pluton separated from a Permian sedimentary basin by a ductile shear

125 zone and a brittle fault system (Coromina and Fabbri 2004).

126

127 3. Petrography and structure of the studied rocks

$128 \quad$ 3.1. Field data

In the Autun area (Fig. 2a), a N70 ${ }^{\circ}$-trending, $500 \mathrm{~m}$ wide, mylonitic belt separates

130 Variscan migmatites and granites to the south from a Stephanian to Autunian coal basin to the

131 north (Delfour et al. 1991; Rolin and Stussi 1991). The Autun leucogranite (Fig. 4a) intruded

132 pre-Carboniferous gneisses and migmatites. A porphyritic facies of this leucogranite can be

133 observed in some places. At the hand sample scale, this granite locally shows a planar

134 preferred orientation of biotite and muscovite, and a linear preferred orientation, indicated by

135 K-feldspar and biotite aggregates. However, given the scarcity of outcrops, it is difficult to

136 draw a structural map of the whole pluton (Fig. 2a). To the north, the granitic rocks are more

137 deformed, and the magmatic foliation is reoriented and changed to a tectonic foliation (Fig 2a;

138 b). This change suggests that either the deformation might have occurred during the last

139 stages of pluton emplacement, or that the granitic pluton experienced a post-solidus ductile

140 deformation along the Autun fault. The mylonitization affects all the Variscan rocks, which

141 then display a $\mathrm{N} 60^{\circ} \mathrm{E}$ to $\mathrm{N} 80^{\circ} \mathrm{E}$ striking foliation that dips $45^{\circ}$ to $80^{\circ}$ to the north; a stretching

142 lineation trends $\mathrm{N} 45^{\circ} \mathrm{E}$ and plunges to the NE (Fig. 2c). Macroscopic shear criteria indicate a

143 top-to-the-NE motion. Shearing was oblique combining strike-slip and dip-slip components

144 (Fig. 4b), not in agreement with previous results on the Autun Shear Zone for which a pure

145 dextral strike-slip faulting was postulated (Rolin and Stussi 1991). North of the shear zone,

146 the mylonites are unconformably overlain by Permian deposits. However, north of Morlet

147 (Fig. 2a), the contact between mylonites to the south and gneiss to the north is a brittle fault

148 hidden westward beneath onlapping Permian deposits (Fig. 2b). Cataclastic mylonitic granites 
149 and silicified tectonic breccia, exposed at the southern border of the sedimentary basin, 150 indicate brittle deformation. In the northern part of the Autun basin, the Permian strata overlie 151 Stephanian strata (Marteau 1983; Chévremont et al. 1999) The Autun basin has been 152 described as either a half-graben bounded by normal faults, or a pull-apart basin associated 153 with left-lateral faults (Marteau 1983). The continental deposits composed of conglomerates 154 and sandstones interlayerd with volcanic deposits (Carpena et al. 1987; Chévremont et al. 155 1999) yielded an Autunian to Saxonian flora described by Bergeron (1889) who defined the 156 Autunian stratotype. Sedimentary filling of this intramontane basin (Courel 2001) is coeval 157 with the activity along the normal boundary fault.

158 Similar structures are observed in the La Serre area (Fig 3a). A two-mica granite 159 (Morre-Biot 1969) with a weak mica preferred orientation is progressively deformed along 160 the $\mathrm{N} 50^{\circ}$ E-trending La Serre Shear Zone, characterized by a N50 E-striking and $60^{\circ}$ - to $80^{\circ}$ 161 northwest-dipping mylonitic foliation and a N30 ${ }^{\circ}$-trending stretching lineation (Coromina 162 and Fabbri 2004; Fig. 3b). In thin sections, perpendicular to the foliation and parallel to the 163 lineation (XZ sections), sigmoidal muscovites, shear bands and asymmetric porphyroclasts 164 indicate a top-to-the-NE shear sense. To the northwest, the mylonitic belt is limited by the $165 \mathrm{~N} 70^{\circ} \mathrm{E}-$ to $\mathrm{N} 80^{\circ} \mathrm{E}$ striking, low angle La Serre Median Brittle Fault, marked by a silicified 166 volcanic breccia (Coromina and Fabbri 2004; Fig 3c). This breccia is similar to the silicified 167 breccia exposed along the Autun shear zone. North of the La Serre Median Brittle Fault, 168 Permian conglomerates and sandstones, with an Upper Autunian to Saxonian continental flora 169 are about $500 \mathrm{~m}$ thick (Campy et al. 1983). The La Serre Median Brittle Fault is postdated by 170 flat lying deposits, but it was probably moderately reactivated as a normal fault during the 171 Oligocene extensional tectonics of the Bresse graben and as a reverse fault during Alpine 172 shortening (Coromina and Fabbri 2004; Madritsch et al. 2008). 
In order to understand the mechanisms of deformation of the Autun and La Serre leucogranites, the rock fabric was studied by several methods. The evolution from a magmatic planar fabric to a tectonic foliation was investigated by relying on mica preferred orientation.

Since rock fabric is not well defined, especially in apparently undeformed granites, systematic manual measurements of the orientation of longitudinal sections of muscovite and biotite

180 platelets were carried out in the three principal planes of the strain ellipsoid (XY, XZ and

181 YZ). These planes were estimated from field observations. Manual measurements were also 182 supported by an automatic method using the "SPO" software (Launeau and Robin 2005). On

183 thin section images, each mica was handled as an isolated grain (Fig. 5). The orientation of

184 each grain was computed by using the intercept method, with measurements shown in rose 185 diagrams (Fig. 5). There are no significant differences between manual and automatic 186 procedures. Quartz lattice-preferred orientation (LPO) analysis provides information about 187 deformation mechanisms, glide systems, and activation temperature. Quartz c-axis orientation 188 (Fig. 6) was studied with an U-stage.

\subsubsection{Magmatic microstructures}

In the two samples of undeformed granite (AU16 and AU19, Fig. 5), a planar fabric

191 can be inferred from the orientation of mica flakes along the XZ and YZ sections. A linear

192 fabric visible along XY sections is better developed in sample AU16 than in sample AU19.

193 Coarse angular quartz grains show seriate to polygonal textures (Moore 1970). Quartz grains

194 display a chessboard pattern of subgrain boundaries (Fig. 4c). Myrmekite is also observed

195 (Fig. 4d) and could indicate a syn-magmatic deformation (Hibbard 1987), although 196 myrmekitic textures can also develop under solid-state conditions (Simpson et Wintsch 1989).

197 In samples from the undeformed Autun and La Serre granites (AU16, AU19, AU28, 198 AU29 and SE03, Fig. 6), c-axis maxima in the XZ plane are observed at 0 to $45^{\circ}$ from the $\mathrm{X}$ 
axis of the finite strain. Such a c-axis distribution is typical of prism $<\mathrm{c}>$ slip and is

200 representative of high-temperature deformation mechanisms (Mainprice et al. 1986).

201 Nevertheless, the chessboard textures observed in the two plutons indicate either a combined

202 basal $<\mathrm{a}>$ and prism $<\mathrm{c}>\operatorname{slip}$ (Mainprice et al. 1986; Stipp et al. 2002), or the transition from

203 low-temperature to high-temperature quartz (Kruhl 1996). Whatever the mechanism is, and

204 considering that no fluids have caused a late recrystallization, microstructures in undeformed

205 granite reveal high temperature of deformation of ca. $700^{\circ} \mathrm{C}$, close to the magma 206 crystallization (Kruhl 1996).

In the two samples of mylonitic granite (AU02 and AU20, Fig. 5), well-defined maxima in the rose diagram correspond to the rock planar fabric. The bimodal orientation of 210 micas probably correlates with distinct shear bands and recrystallization of mica. In the 211 mylonitic granite, microstructures are characteristic of ductile deformation with shear bands 212 crosscutting a preexisting foliation (Fig. 4b). This geometry must be distinguished from the S-

213 C structures, which have been originally defined for a synkinematic pluton where S and C 214 surfaces are formed synchronously (Berthé et al. 1979). During mylonitization, the granite 215 experienced grain size reduction; undulatory quartz grains with lobate boundaries indicate 216 dynamic recrystallization during low-temperature deformation (Fig. 4e). Recrystallization of 217 such fine quartz grains may be due to combined subgrain rotation and bulging 218 recrystallizations (Stipp et al., 2002). The asymmetry of feldspar porphryroclasts with sigma219 type recrystallization tails (Fig. 4f), sigmoidal micafish (Fig. 4g), quartz ribbons, and shear 220 band geometry suggest a non-coaxial strain regime with a top-to-the-NE sense of shear (Fig. 221 4h, Passchier and Trouw 2005), in agreement with a normal-dextral sense of the shear. In deformed granite samples (AU02, AU03, AU04, AU20, SE01 and SE02, Fig. 6), 223 quartz c-axis measurements reveal an incomplete type I crossed griddle pattern (Lister and 
224 Hobbs 1980). Maxima around the main shortening direction axis (Z) indicate activity of basal $225<\mathrm{a}>$ slip systems, and the dominant recrystallization mechanism is bulging recrystallization 226 (Stipp et al. 2002). Submaxima distributed either close to the $\mathrm{Y}$ axis, or in between the $\mathrm{Y}$ and

$227 \mathrm{Z}$ axes stem from prism $<\mathrm{a}>$ and rhomb $<\mathrm{a}>$ slips (Bouchez 1977), with dominant subgrain 228 rotation recrystallization (Stipp et al. 2002). The coexistence of these slip systems may be due 229 to different activation temperature; at ca. $300^{\circ} \mathrm{C}$, basal $<\mathrm{a}>$ slip is dominant, whereas, at $230500^{\circ} \mathrm{C}$, prism $<\mathrm{a}>$ is more important (Bouchez 1977; Stipp et al. 2002; Passchier and Trouw 231 2005) However, at low temperature, with an increasing strain, the slip sequence is basal $<\mathrm{a}>$, 232 followed by prism $<\mathrm{a}>$, and finally rhomb $<\mathrm{a}>$ (Passchier and Trouw 2005). Since basal $<\mathrm{a}>$ 233 slips are mainly observed in protomylonites, and both prism $<\mathrm{a}>$ and $\mathrm{rhomb}>\mathrm{a}>$ slips are 234 dominant in the most deformed mylonites (Fig. 6), the second alternative seems more likely. 235 The asymmetry of the c-axis maxima suggests a non-coaxial progressive deformation, under 236 low to intermediate temperature, with a top-to-NE sense of shear in agreement with other 237 kinematic indicators.

\section{New geochronological data}

To constrain the age of the granitoid emplacement and the time of the ductile deformation, monazite $\mathrm{U}-\mathrm{Th}-\mathrm{Pb}$ geochronology and micas ${ }^{40} \mathrm{Ar} /{ }^{39} \mathrm{Ar}$ dating have been carried out.

\subsection{Electron microprobe (EPMA) monazite geochronology}

The EPMA U-Th-Pb dating on monazite is a chemical method based on two main assumptions related to the mineral structure. (1) The common lead incorporated in monazite

247 during crystallization is negligible compared to the amount of radiogenic lead (Parrish 1990; 248 Cocherie et al. 1998), and (2) no radiogenic lead loss occurred since the system closure 
249 (considered as the crystallization time in magmatic rocks). These assumptions have been 250 confirmed both by experimental studies, and by comparison of EPMA dating and 251 conventional $\mathrm{U} / \mathrm{Pb}$ isotopic methods (Cocherie et al. 1998; 2005; Montel et al. 2002). 252 Moreover, altered domains with potential lead loss can be avoided with the EPMA resolution $253(2 \mu \mathrm{m})$ associated with Backscattered Electron (BSE) microscopy. This monazite EPMA 254 method is well suited for the dating of leucogranite, as monazite is common in peraluminous 255 granite (e.g. Bé Mézème et al. 2006). In-situ monazite grains were analyzed with a Cameca SX 50 electron microprobe, cooperated by ITSO and BRGM, following the analytical procedure described in Cocherie et al. (1998). Acceleration voltage is $20 \mathrm{kV}$, beam current is $200 \mathrm{nA}$, and $\mathrm{U}, \mathrm{Th}, \mathrm{Pb}$ absolute errors are $105 \mathrm{ppm}, 130 \mathrm{ppm}$ and $110 \mathrm{ppm}$, respectively. The U-Th-Pb age calculations were done 260 by using the "EPMA dating" program written by Pommier et al. (2002). The age calculated 261 for each microprobe point analysis is rejected if out of the confidence range. The sorted 262 results are computed and plotted with the ISOPLOT program (Ludwig 1999; 2003). Due to a 263 relatively large range in $\mathrm{Th} / \mathrm{U}$ ratios, the isochron method of Cocherie and Albarede (2001) 264 was used to produce the $\mathrm{U} / \mathrm{Pb}$ vs $\mathrm{Th} / \mathrm{Pb}$ diagrams reported in Figure 6 . The following 265 parameters were extracted from the diagram and used to compute the best fit line age 266 calculation for each sample: (1) Th- $\mathrm{Pb}$ age (intercept with $\mathrm{Th} / \mathrm{Pb}$ axis) and $\mathrm{U}-\mathrm{Pb}$ age

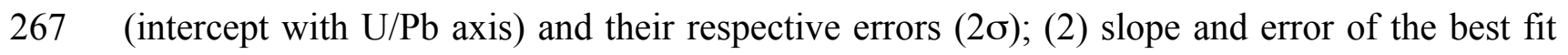
268 line, $\mathrm{X}-\mathrm{Y}$ coordinates of the centroid of the best fit line. The results are statistically acceptable 269 if the following three conditions are fullfilled. : (1) The theoretical Mean Square Weight 270 Deviation (MSWD) is above the calculated MSWD, (2) the theoretical isochron crosscuts the 271 envelope error of each analysis and (3) the intercept ages are similar within the error margin. In the studied samples, monazite grains are included in biotite and predate the 273 crystallization of the mica (Fig 7a). BSE images (Fig. 7b) of monazite in the Autun 
undeformed leucogranite (AU16, N46 55'55', E4¹9'22'’) show medium-sized euhedral to

275 sub-euhedral grains (50 to $100 \mu \mathrm{m}$ ) with no significant chemical zoning. The data scatter is 276 relatively good and an isochron age of $318 \pm 7$ Ma has been calculated on 8 grains (Fig. 7b).

277 The MSWD is slightly higher than the theoretical value (1.5 vs. 1.4).

BSE images of monazite in mylonitic Autun leucogranites sample (AU26, N46 $\left.57^{\prime} 00^{\prime \prime} ; 4^{\circ} 21^{\prime} 35^{\prime \prime}\right)$ show euhedral grains not deformed during the ductile event and still exhibiting typical growth zoning (Fig. 7c). Most of the analyses are clustered but, since some analyses show a high $\mathrm{U} / \mathrm{Pb}$ ratio, a best fit line can be drawn, and an isochron age of $321 \pm 3$ Ma has been calculated on 5 grains (Fig. 7c). The intercept ages (U-Pb age $323 \pm 6 \mathrm{Ma}$ and Th$\mathrm{Pb}$ age: $306 \pm 36 \mathrm{Ma}$ ) are similar within errors. The MSWD is largely below the theorical value (0.23 vs. 1.30), a statistically meaningful result.

BSE images of monazite in the La Serre granite (SE03, N47¹0'20"; E5³3'24") show medium-sized sub-euhedral to anhedral grains (Fig. 7d). The data are widely spread in the isochron diagram and a best fit line can be drawn. The calculation on 6 grains provides an isochron age of $317 \pm 5 \mathrm{Ma}$ (Fig. 7d). Although the theoretical isochron is at the limit of the error envelope of the best fit line, the results are acceptable as the intercept ages (U-Pb age $290 \pm 30 \mathrm{Ma}$ and $\mathrm{Th}-\mathrm{Pb}$ age: $338 \pm 25 \mathrm{Ma}$ ) are similar within error magin, and the calculated MSWD is slightly lower than its theoretical value (1.3 vs. 1.38).

In order to date the ductile faulting and to constrain the relationships between magmatism and deformation, we performed ${ }^{40} \mathrm{Ar} /{ }^{39} \mathrm{Ar}$ dating on mylonites from the two shear zones and on the Autun granite, and assumed that muscovite and biotite ages from these samples would

297 provide constraints on their cooling history in the $300^{\circ} \mathrm{C}-450^{\circ} \mathrm{C}$ range (Harrison et al. 1985 , 298 2009; Hames and Bowring 1994). As these cooling temperatures are similar to those deduced 
299 from LPO measurements in mylonitic rocks, the ${ }^{40} \mathrm{Ar} /{ }^{39} \mathrm{Ar}$ method should give a reliable 300 estimate of the age of deformation and an estimate of the cooling rate of the granite.

301 Details about the analytical procedure for laser probe ${ }^{40} \mathrm{Ar} /{ }^{39} \mathrm{Ar}$ dating can be found in 302 York et al. (1981), Dalrymple (1989), McDougall and Harrison (1999), Monié et al. (1994) 303 and Monié and Agard (2009). Each sample was first crushed and micas were separated under 304 a binocular from the $0.5-07 \mathrm{~mm}$ size fraction. After ultrasonic cleaning, micas were enveloped 305 in aluminium foils and irradiated at McMaster (Canada) together with several aliquots of the 306 MMhb1 monitor amphibole (520.4 \pm 1.7 Ma; Samson and Alexander 1987). After irradiation, 307 the micas and standards were placed on a copper holder inside the sample chamber and heated 308 at $150^{\circ} \mathrm{C}$ under ultrahigh vacuum. Step-heating degassing of individual grains was performed 309 using a continuous $\mathrm{CO}_{2}$ laser until complete fusion of the mineral. For each step, the released 310 gas was cleaned on getters and then introduced in a MAP 215-250 mass spectrometer for 311 analysis of the isotopic composition, estimated by regression on 15 runs. Extraction, cleaning, 312 and analysing processes involve 1,2 and 8 minutes respectively. System blanks were realized 313 every three experiments. Depending on the samples, 9 to 17 steps were performed. Individual 314 age (Tab. 1) was calculated after usual isotope corrections including blanks, mass 315 discrimination, radioactive decay of ${ }^{37} \mathrm{Ar}$ and ${ }^{39} \mathrm{Ar}$, and irradiation-induced mass interference. 316 For the MAP 215-250 mass spectrometer, a ${ }^{40} \mathrm{Ar} /{ }^{36} \mathrm{Ar}$ ratio of $285.0 \pm 2.0$ was used for mass 317 discrimination of all analyses. The uncertainty on the J-factor was propagated in the 318 calculation of the error on the total age of each sample, equivalent to a $\mathrm{K}-\mathrm{Ar}$ age. Results are 319 reported as classical ${ }^{40} \mathrm{Ar} /{ }^{39} \mathrm{Ar}$ age spectra (Fig. 8).

320 The term "plateau age" is defined as the segment of a spectrum, made of three consecutive 321 steps, containing more than $70 \%$ of the total ${ }^{39} \mathrm{Ar}$ released, and whose ages overlap within two 322 sigma errors (McDougall and Harrison, 1999). Ages are reported with a $1 \sigma$ uncertainty. It is 323 worth to mention that the Autun shear zone experienced an important fluid circulation that 
caused silicification, galena mineralization and secondary large muscovite flake crystallization, probably during late brittle faulting (Delfour et al., 1991). Since this alteration event possibly influenced the argon isotopic system, only unaltered samples were choosen.

Biotite from the inner part of the Autun granitic massif shows a discordant spectrum with ages varying from $297 \mathrm{Ma}$ to $308 \mathrm{Ma}$ and a plateau age of $306.4 \pm 4$ Ma calculated on the last $70 \%$ of ${ }^{39} \mathrm{Ar}$ released (sample AU29, N46 54'30"; E4²16'20", Fig. 8a). Muscovite from the Autun protomylonite (sample AU17, N4656'9”; E4¹9'10”, Fig. 8b) displays a slightly discordant spectrum with ages ranging from 261 to $355 \mathrm{Ma}$. More than $80 \%$ of the total ${ }^{39} \mathrm{Ar}$ released gives a plateau age of $303.9 \pm 3 \mathrm{Ma}$ in the intermediate portion of the spectrum.

Biotite from the Autun granite (AU16, N46'55'55',; E4¹9’22', Fig. 8c) has a discordant spectrum with evidence of argon loss at the beginning of degassing and excess argon at the end, resulting in ages varying from $133 \mathrm{Ma}$ to $310 \mathrm{Ma}$. A plateau age of $299.6 \pm 3 \mathrm{Ma}$ has been calculated on more than $75 \%$ of ${ }^{39} \mathrm{Ar}$ released in the intermediate portion of the spectrum. Muscovite from sample AU16 (Fig. 8d) shows a relatively flat spectrum with values ranging mainly between $291 \mathrm{Ma}$ and $301 \mathrm{Ma}$, with the exception of the first step related to argon bound to the mica surface. A plateau age of $299.8 \pm 3 \mathrm{Ma}$ is calculated for more than $80 \%$ of the total ${ }^{39} \mathrm{Ar}$ released.

Biotite from the Autun mylonite (AU15, N4656'24', E4¹8'53', Fig. 8e) displays a highly discordant spectrum with ages varying from $220 \mathrm{Ma}$ to $303 \mathrm{Ma}$ and no plateau age. It is likely that incipient chloritization is responsible for such a pattern, with combined effects of argon loss and neutron-induced ${ }^{39}$ Ar recoil (Turner and Cadogan, 1974; Ruffet et al., 1991). Muscovite from sample AU15 gives a much less discordant spectrum with young ages for low experimental temperatures (Fig. 8e). With the exception of the three first steps, the ages are bracketed between 295 and $304 \mathrm{Ma}$, and a plateau age of $299.8 \pm 3.0$ can be calculated on $95 \%$ of the total ${ }^{39}$ Ar released. 
Muscovite from the La Serre mylonite (sample SE01Ms, 47¹1'19"; 5³1'27", Fig. 8f) displays a discordant spectrum ranging from 289 to $321 \mathrm{Ma}$, with argon excess released at

351 low experimental temperature. However for $75 \%$ of the total ${ }^{39} \mathrm{Ar}$ released, ages are 352 bracketed between $296 \mathrm{Ma}$ and $299 \mathrm{Ma}$ and correspond to a plateau age of $298.2 \pm 3 \mathrm{Ma}$. In 353 this sample, the deformation is very strong, and biotite is often replaced by chlorite.

5. Discussion

Massif Central remained speculative for a long time (Arthaud and Matte 1977). Rolin and 360 Stussi (1991) considered the Autun Shear Zone as an Upper Devonian to Middle 361 Carboniferous dextral wrench fault and, after restoring the sinistral offset of the Sillon 362 Houiller Fault, correlated it with the Marche-Combrailles Fault (see also Lerouge and 363 Quenardel 1985; Rolin \& Colchen 2001). However, our new data and other recent ${ }^{40} \mathrm{Ar}-{ }^{39} \mathrm{Ar}$ 364 dating in the La Marche area (Gebelin et al. 2007) indicate that the Marche-Combrailles and 365 the Autun shear zones are two different shear zones. Recent geophysical studies also suggest 366 that the eastern continuation of the Marche-Combrailles Fault is the Avallon Fault (Edel 367 2008; Fig. 9). The eastern continuation of the Autun Shear zone is less hypothetic, as shown 368 by the similar structures observed along the La Serre Fault Zone. After restoring the E-W 369 offset related to the Cenozoic opening of the Bresse graben, the two areas belong to the same 370 fault system. However, vertical derivation of the Bouguer gravity anomaly map does not 371 support a direct continuity between the two shear zones (Edel, unpublished data), but rather 372 suggest that the Autun Shear Zone joins a fault zone parallel to the La Serre Shear Zone, 373 located about $10 \mathrm{~km}$ to the north of the La Serre Shear Zone. The southwestern extension of 
374 the $\mathrm{N}^{\circ} 5^{\circ} \mathrm{E}$ trending La Serre brittle Fault might be the fault that rims the Creusot Basin (Fig.

375 1). Presently, there is no evidence of the western continuation of the La Serre ductile shear 376 zone to the Morvan area. The La Serre ductile shear zone may extend westward below the

377 Creusot sedimentary basin. All these E-W to $\mathrm{N} 65^{\circ} \mathrm{E}$ trending faults are crosscut by the La 378 Serre Southern brittle Fault (Fig. 3), a segment of the NE-SW striking Sainte-Marie-Aux379 Mines Fault. This sinistral fault hides the eastern extension of the Autun-La Serre fault system 380 (Fig. 9). However, recent work on the Upper Rhine graben (Edel et al. 2007; Ustaszewski and 381 Schmid 2007) and along the Rhine-Bresse Transfer Zone (Madritsch et al. 2008) indicate the 382 presence beneath the Mesozoic sedimentary cover of a large set of NE-SW to E-W pre383 Mesozoic steeply dipping faults that might represent the eastern continuations of the Autun384 La Serre fault system (Fig. 9). These Variscan faults were locally reactivated by the Late 385 Eocene-Oligocene extension in the Upper Rhine graben (Edel et al. 2007) or by the Pliocene 386 shortening during formation of the Jura fold-and-thrust belt (Giamboni et al. 2004). The 387 gentle curvature of the Autun La Serre Fault System, from an E-W trend, to the west, to an 388 ENE-WSW trend, to the east, could be related to local block rotations either due to Late 389 Variscan adjustments as suggested by Edel and Schulmann (2007) or by Oligocene extension 390 in the Bresse graben, or due to Pliocene tectonics of the Jura Mountains. Microstructural observations, and shape and lattice preferred orientation analyses 394 indicate several types of deformation. As deduced from quartz $<\mathrm{c}>$ axis measurements and 395 chessboard pattern, the Autun and La Serre plutons underwent a high-temperature 396 deformation, the mechanisms of which remains controversial; it could be either be due to 397 prism $<\mathrm{c}>\operatorname{slip}$ (Mainprice et al. 1986) or grain growth and boundary migration (Gapais and 398 Barbarin 1986) or $\alpha$ to $\beta$ quartz transition (Kruhl 1996). Whatever the mechanism is, 
deformation likely occurred during granite emplacement. Furthermore, low- to intermediate temperature shearing in protomylonites, mylonites and ultramylonites indicates a strain

401 gradient from the pluton margin, where a tectonic fabric dominates, to the pluton core, where sub-solidus preferred orientation is prominent. Such a strain gradient could be due to localized deformation either during magma crystallization or under solid-state conditions after 404 granite emplacement.

Monazite $\mathrm{U}-\mathrm{Th} / \mathrm{Pb}$ dating yields consistent ages at ca. 320-318 Ma (Namurian) for the 406 Autun and La Serre granites and the Autun mylonitic granite, indicating that the U-Th- $\mathrm{Pb}$ system was not reset during deformation (Figs. 7 and 10). A modification of the chemistry of 408 the monazite can occur in amphibolite facies shear zones (Berger et al. 2006) but, in the 409 present case, the lack of core-and-mantle zoned grains and the preservation of growth zoning suggest that monazite grains did not recrystallize during mylonitization. Moreover, since the 411 dated monazites are included in biotite, they predate the crystallization of the micas. 412 Crystallization of magmatic monazite in peraluminous systems occurs during granite 413 emplacement (Braun et al. 1998; Förster 1998), at temperatures of about $900^{\circ} \mathrm{C}($ Cherniak et 414 al. 2004). Thus, the monazite $\mathrm{U}-\mathrm{Th} / \mathrm{Pb}$ ages mirror the crystallization age of the magma. The 415 Namurian age assignment is significantly different from the Stephanian age previously 416 proposed for the Autun granite (Rolin and Stussi 1991) and from the Devonian U-Pb (TIMS) 417 age proposed for the La Serre granite (Morre-Biot and Storet 1967). The consistency between 418 our new monazite $\mathrm{U}-\mathrm{Th} / \mathrm{Pb}$ ages and the petrographic and microstructural observations 419 reveals that mylonite formed at the expense of the Autun granite. During the pluton 420 emplacement, a poorly defined subsolidus fabric was acquired. However, the significance of 421 this magmatic preferred orientation is not clear and might be due to magmatic processes in the 422 magma chamber or to a combination of magma dynamics and regional tectonics (Brun and 423 Pons 1981). 
Whatever the deformation gradient obtained in the Autun and La Serre areas might be, 425 the Late Carboniferous ${ }^{40} \mathrm{Ar} /{ }^{39} \mathrm{Ar}$ ages around 300 Ma show a regional consistency (Figs. 8 and 10a). One interpretation could be that a Late Carboniferous thermal event reset the argon isotopic system, a phenomenon recognized for the Late Visean evolution in the central part of the French Massif Central (Faure et al. 2002). Although a Stephanian to Permian volcanism is recorded in the northeastern part of the French Massif Central (Carpena et al. 1987;

430 Chévremont et al. 1999), it seems to be too scattered and too small in volume to have caused 431 such a large thermal overprint. ranging from 305 to $300 \mathrm{Ma}$ (Fig. 8), representing the time when the cooling path of the

434 granite intersected the mica closure temperature. Due to their different closure temperatures, 435 the concordance between muscovite and biotite ${ }^{40} \mathrm{Ar} /{ }^{39} \mathrm{Ar}$ ages indicates a fast cooling between $400^{\circ} \mathrm{C}$ and $300^{\circ} \mathrm{C}$. The ${ }^{40} \mathrm{Ar} /{ }^{39} \mathrm{Ar}$ plateau age of undeformed rocks is statistically undistinguishable from those of mylonites (Figs. 8 and 10a). The range of closure temperature of the two micas is similar to the temperature interval in which quartz lattice slip was activated. The Stephanian age thus likely corresponds to the time of the low-temperature non440 coaxial ductile deformation experienced by the Autun and La Serre plutons. The age of this 441 ductile deformation is furthermore constrained by the Lower Autunian (303 Ma to $290 \mathrm{Ma}$ ) 442 sedimentary deposits of the Autun basin (Fig. 10). The earliest activity along the Autun-La 443 Serre shear zone remains unknown, as ${ }^{40} \mathrm{Ar}-{ }^{39} \mathrm{Ar}$ dating only provides the age of the youngest 444 ductile motion. Deformation the Autun-La Serre Fault System might have started before 305 445 Ma. However, several lines of evidence suggest that these granites are not syntectonic 446 plutons. High-temperature post-solidus shearing could not be demonstrated in the analyzed 447 rocks and only magmatic sub-solidus textures are observed in undeformed granites. 448 Moreover, the time gap of at least 15 myrs between granite emplacement and the last shear 
motion would imply a long-lived localized tectonic zone. As described in the geological 450 outline section, such a time gap is not documented in the French Massif Central, where the 451 Namurian - Westphalian NW-SE extension was followed by the Stephanian - Permian NE452 SW extension (Faure and Becq-Giraudon 1993; Faure 1995). If a syntectonic granite had been 453 emplaced in Namurian times, it would probably have recorded the NW-SE stretching 454 associated with the widespread first extensional stage, (Faure 1995; Talbot et al. 2005; Joly et 455 al. 2009).

456 Our results demonstrate the existence of a Stephanian - Autunian NE-SW Autun-La Serre 457 transtensional shear zone system. Its age is slightly younger than the Westphalian to 458 Stephanian Pilat detachement fault that shows similar mechanisms and structures (Malavieille 459 et al. 1990). Although well documented (Burg et al. 1994; Faure 1995), the Stephanian 460 Permian NE-SW stretching must be distinguished from the NW-SE Namurian - Westphalian 461 extension reported from the western part of the Massif Central (Faure, 1995). Extensional 462 structures are also documented beyond the Rhine Bresse transfer zone in the Vosges 463 Mountains and Black Forest. Similar to the French Massif Central, the convergence of 464 Gondwana and Laurussia has resulted in thrust tectonics and metamorphism in the Vosges 465 Mountains (Fluck et al., 1987; Rey et al. 1989; Schulmann et al. 2002), and in the Black 466 Forest (Wickert and Eisbacher, 1988; Eisbacher et al., 1989; Echtler and Chauvet 1992;). The 467 thickened crust experienced syn-orogenic to post-orogenic extension represented by 468 detachment faults and syntectonic plutons, documented in the Vosges Mountains (Rey et al. 469 1992; Kratinova et al. 2007), and in the Black Forest (Krohe and Eisbacher 1988; Eisbacher et 470 al. 1989; Echtler and Chauvet, 1992).

472 5.3. Implications for the thermal conditions during post-orogenic extension 

around $300 \mathrm{Ma}$ and are ca. 15 myrs younger than the monazite U-Th-Pb ages of pluton emplacement, the contemporaneity between the emplacement of plutons and the oblique-slip displacement along the Autun-La Serre Shear Zone is ruled out. However, additional geochronological studies are required to solve the question of « the synkinematic granites ». granite is larger than ca. 5 myrs cooling times from $750^{\circ} \mathrm{C}$ (emplacement temperature) to $300^{\circ} \mathrm{C}$, experimentally established for similarly-sized leucogranites (Annen et al. 2006; Annen and Scaillet 2006). We propose two different cooling paths (Fig. 10b). One two-stage cooling path is characterized by a "normal cooling" during the first 5 myrs, with a $100^{\circ} \mathrm{C} / \mathrm{Myr}$ cooling rate, followed by a 10 myrs steady-state step around $300^{\circ} \mathrm{C}$; in this case, ${ }^{40} \mathrm{Ar}-{ }^{39} \mathrm{Ar}$ ages of micas in undeformed granites should be close to $\mathrm{U}-\mathrm{Th} / \mathrm{Pb}$ ages and significantly older than age of mylonitization. An alternative cooling model could be a single step path, with continuous cooling from $800^{\circ} \mathrm{C}$ at $320 \mathrm{Ma}$ to $300^{\circ} \mathrm{C}$ at $305 \mathrm{Ma}$. Such a $500^{\circ} \mathrm{C}$ temperature drop in 15 myrs represents a $33^{\circ} \mathrm{C} / \mathrm{myr}$ cooling rate. Such a slow rate would require a constant heat flow during the Late Carboniferous in order to maintain a high mean crustal temperature. The formation of the Velay migmatitic dome (Ledru et al. 2001) is characterized by a Late Carboniferous continuous melting of the metasediments of the lower crust. Crustal melting, assisted by underplating of mantle-derived magma (Williamson et al. 1996) from asthenospheric upwelling (Ledru et al. 2001), supports the existence of a regional high heat

493 flow hypothesis in the Eastern Massif Central. However, this thermal anomaly remains 494 limited to the Velay area, and indications of an important Westphalian and Stephanian magmatism are lacking in the Morvan, Vosges and Black Forest areas. The rare Stephanian 496 shoshonites in the Epinac basin (Chévremont et al., 1999) cannot account for a continuous 497 heat flow during the 315-300 Ma period. The most significant magmatic event recorded in 
Morvan, Vosges and Black Forest areas dates back to Early Permian times (Lippolt and Hess, 1983; Carpena et al., 1987). The current available data do not allow to determine which cooling path did the Autun and La Serre plutons follow. Autun-La Serre transtensional fault system. The normal component deduced from field observations and microstructural analysis could have accommodated the rapid exhumation indicated by the cooling between $400^{\circ} \mathrm{C}$ and $300^{\circ} \mathrm{C}$ and by the rapid transition from ductile conditions along the shear zone at $300 \mathrm{Ma}$ to brittle, normal, syn-sedimentary faulting at around $297 \mathrm{Ma}$ (Figs. 8 and 10a). Such a ductile-brittle continuum is known in the Aegean extensional realm (Mehl et al. 2005) and also in the Massif Armoricain (Turrillot et al.

508 submitted). In the Autun region, the ductile-brittle transition is also marked by a rotation of 509 the stretching direction from NE-SW in Stephanian - Early Autunian times to N-S in Late 510 Autunian times (Marteau 1983; Faure 1995). Under brittle conditions, exhumation continued 511 during Autunian times, accomodated by normal faulting. Evidence for Autunian normal 512 faulting can be observed in the sedimentary basin of Autun, where at least $1200 \mathrm{~m}$ of detrital 513 lacustrine and fluviatile sediments accumulated (Chévremont et al. 1999). Moreover, in the 514 sedimentary filling of the Autun basin, plant fragments were buried and transformed into coal. 515 Coalification requires rapid burial to ensure the preservation of the organic matter. The huge 516 abundance of coal in the Autun basin suggests that the subsidence of the basin was 517 tectonically controlled and was probably coeval with a rapid exhumation of the Variscan 518 basement.

In the northeastern French Massif Central, the post-orogenic evolution is characterized by Namurian - Westphalian granite emplacement followed by Stephanian - Autunian NE-SW extension. This last stage contributed to the exhumation of the Variscan rocks, although it remains difficult to propose an exhumation rate for the Stephanian - Permian period since the 
geothermal gradient at that time is unknown and since the estimation of the P-T conditions of the granite before the initiation of the deformation is not available. The two-stages extension interpretation agrees with Faure (1995) who pointed out that the Namurian - Westphalian extension is more pronounced in the western part of the French Massif Central than in the eastern part, where Stephanian to Permian extension is well recorded. The extensional processes thus appear to be subdivided into small intervals of regionally localized shearina and related to a large period of crustal melting.

\section{Conclusion}

New structural and geochronological data on the Autun and La Serre areas constrain the Late Variscan evolution of the northeastern part of the French Massif Central. The similarity between the Autun and La Serre shear zones suggests the existence of an ENEWSW trending fault system, which was probably reactivated under brittle conditions during the Cenozoic. The major results include: 1) the recognition of normal-dextral ductile shear zones and 2) documentation of a diachronism of ca. 15 myrs between the Namurian Westphalian pluton emplacement and the Stephanian - Permian extensional tectonics and basin subsidence. The Stephanian - Autunian Autun and La Serre shear zones affected the Namurian plutons during their post-emplacement cooling, but these plutons are not synkinematic. This shows that the widespread idea of synkinematic plutonism as as a characteristic of late-orogenic to post-orogenic extension suffers exceptions. Several points remain unclear, such as the tectonic setting during the emplacement of the Autun pluton. More detailed studies, such as a study of the anisotropy of the magnetic susceptibility of the pluton, could improve our understanding of the Namurian - Westphalian extensional stage and its relationships with plutonism. 
Acknowledgements

549 This work is a part of F. Choulet's master thesis dissertation. Field and analytical expenses

550 have been funded by ISTO and Chrono-environnement. Alain Cocherie is acknowledged for

551 his help during monazite U-Th-Pb calculations. The authors thank G. Eisbaher and J-B Edel,

552 for constructive review.

553

554 References

Annen C, Scaillet B (2006) Thermal evolution of leucogranites in extensional faults:

556 implications for Miocene denudation rates in the Himalaya. Special Publication 268, 557 Geological Society, London pp 309-326

Annen C, Scaillet B,. Sparks RSJ (2006) Thermal Constraints on the Emplacement 559 Rate of a Large Intrusive Complex: The Manaslu Leucogranite, Nepal Himalaya. J Petrol $560 \quad 47: 71-95$

Arthaud F, Matte P (1977) Late Paleozoic strike-slip faulting in southern Europe and 562 northern Africa: Result of a right-lateral shear zone between the Appalachians and the Urals. 563 GSA Bull 88:1305-1320, doi: 10.1130/0016-7606.

Bé Mézème E, Cocherie A, Faure M, Legendre O, Rossi P (2006) Electron 565 microprobe monazite geochronology of magmatic events: Examples from Variscan 566 migmatites and granitoids, Massif Central, France. Lithos 87:276-288

567 Berger A, Herwegh M, Gnos E (2006) Deformation of monazite in an amphibolite568 facies shear zone. Geochem Cosmochim Acta 70:18 Supp. 1 A47 Bergeron J (1889) Etude géologique du Massif ancien situé au Sud du Plateau Central.

570 Thèse Fac. Sci. Paris Ann Sci Géol, Masson, Paris 
572 déformation of granites: the example of the South Armorican Shear Zone. J Struct Geol 1:31-

573

574

575 34

Bouchez J-L (1977) Plastic deformation of quartzites at low temperature in an area of natural strain gradient. Tectonophysics 39:25-50

Braun I, Montel J-M, Nicollet C (1998) Electron microprobe dating of monazite from high-grade gneisses and pegmatites of the Kerala Khondalite Belt, southern India. Chem Geol $146: 65-85$

Brun J-P, Pons J (1981) Strain patterns of pluton emplacement en a crust undergoing non-coaxial deformation, Sierra Morena, Southern Spain. J Struct Geol 3:219-229

Burg J-P, Matte P (1978) A cross-section through the French Massif Central and the scope of its Variscan geodynamic evolution. Ztg Dtsch Geol Ges 109:429-460

Burg J-P, Van den Driessche J, Brun J-P (1994) Syn-to post-thickening extension in the Variscan Belt of Western Europe: Modes and structural consequences. Géologie de la France 3:33-51.

Campy M, Chauve P, Pernin C (1983) Notice explicative de la carte géologique de Pesmes au 1:50000, Bureau de recherches géologiques et minières, Orléans

Carpena J, Doubinger J, Guérin R, Juteau J, Monnier M (1987) Le volcanisme acide de l'Ouest Morvan dans son cadre géologique: caractérisation géochimique, structurale et chronologique de mise en place. Bull Soc Géol Fr 7:839-859

Cherniak DJ, Watson EB, Grove M, Harrison TM (2004) Pb diffusion in monazite: a combine RBS/SIMS study. Geochem Cosmochim Acta 68:829-840

Chévremont P, Rémond C, Marteau P et al (1999) Notice explicative de la carte géologique d'Epinac-Les-Mines au 1:50000, Bureau de recherches géologiques et minières, Orléans 
Cocherie A, Albarède F (2001) An improved U-Th-Pb age calculation for electron microprobe dating of monazite. Geochem Cosmochim Acta 65:4509-4522

Cocherie A, Legendre O, Peucat J-J, Kouamelan AN (1998) Geochronology of polygenetic monazites constrained by in situ electron microprobe Th-U-total $\mathrm{Pb}$ determination: implications for lead behaviour in monazite. Geochem Cosmochim Acta $62: 2475-2497$

Cocherie A, Bé Mézème E, Legendre O, Fanning CM, Faure M, Rossi P (2005) Electron-microprobe dating as a tool for determining the closure of $\mathrm{Th}-\mathrm{U}-\mathrm{Pb}$ systems in migmatitic monazites. Am Mineral 90:607-618

Coromina G, Fabbri O (2004) Late Palaeozoic NE-SW ductile-brittle extension in the La Serre horst, eastern France. C R Geoscience 336:75-84

Courel L (2001) Histoire tardi-hercynienne et couverture méso-cénozoïque. Géologues $130-131: 47-49$

Dalrymple GB (1989) The GLM continuous laser system for. ${ }^{40} \mathrm{Ar} /{ }^{39} \mathrm{Ar}$ dating: description and performance characteristics. US Geol Surv Bull 1890:89-96

Delfour J, Arène J, Clozier L, Carroue J-P, Cornet J, Delance J-H, Feys R, Lemière B (1991) Notice explicative de la carte géologique d'Autun au 1:50000, Bureau de recherches géologiques et minières, Orléans

Delfour J (1989) Données lithostratigraphiques et géochimiques sur le DévonoDinantien de la partie sud du faisceau du Morvan (nord-est du Massif Central français). Géologie de la France 4:49-77

Dewey J (1988) Extensionnal collapse of orogens. Tectonics 7:1123-1139

Duthou J-L, Cantagrel J-M, Didier J, Vialette Y (1984) Palaeozoic granitoids from the French Massif Central: age and origin studied by ${ }^{87} \mathrm{Rb}-{ }^{87} \mathrm{Sr}$ system. Phy Earth Planet Inter $35: 131-144$ 
Echtler H, Chauvet A (1992) Carboniferous convergence and subsequent crustal

extension in the southern Schwarzwald (SW Germany). Geodin Acta 5:37-49

Echtler H, Malavieille J (1990) Extensional tectonics, basement uplift and Stephano-

Permian collapse basin in a late Variscan metamorphic core complex (Montagne Noire, Southern Massif Central). Tectonophysics 177:125-138

Edel J-B, Schulmann K, Rotstein Y (2007) The Variscan tectonic inheritance of the Upper Rhine Graben: evidence of reactivations in the Lias, Late Eocene-Oligocene up to the recent. Int J Earth Sci 96:305-325

Edel J-B, Schulmann K (2007) Paleomagnetic constraints on the evolution of the Variscan belt in Carboniferous times. In: Schulmann K, Ledru P, Faure M, Lardeaux J-M (eds.) Mechanics of Variscan Orogeny: a modern view on orogenic research. Sept 2007, Orléans, Abstr Vol.

Edel J-B (2008) Structure et nature du socle anté-permien du Bassin de Paris d'après les données gravimétriques et magnétiques - Le problème de l'Anomalie Magnétique du Bassin de Paris (AMBP). Géochronique 105:31-37

Eisbacher GH, Lüschen E, Wickert F (1988) Crustal-scale thrusting and extension in the Hercynian Schwarzwald and Vosges, Central Europe. Tectonics 8:1-21

England PC, Thompson AB (1986) Some thermal and tectonic models for crustal melting in continental collision zones. In Coward MP, Ries AC (eds.) Collision tectonics. Geological society of London, Special Publication, 19:83-94

Faure M, Becq-Giraudon J-F (1993) Sur la succession des épisodes extensifs au cours du dés-épaississement carbonifère du Massif Central français. C R Acad Sci, Paris 316:967973 
645 Westphalian leucogranite in the Variscan Belt of the Northwest Massif Central, France. 646 Geology 19:730-733

Faure M, Leloix C, Roig J-Y (1997) L'évolution polycyclique de la chaîne

648 hercynienne. Bull Soc Géol Fr 168:839-859

Faure M, Bé Mézème E, Duguet M, Cartier C, Talbot J (2005) Paleozoic tectonic evolution of medio-europa from the example of the French massif central and massif armoricain. In: (eds.) Carosi R. Dias R. Iacopini D. and Rosenbaum G. The southern Variscan belt, Journal of the Virtual Explorer 19 (5)

Faure M, Bé Mézème E, Cocherie A, Rossi P, Chemenda A, Boutelier D (2008) Devonian geodynamic evolution of the Variscan Belt, insights from the French Massif Central and Massif Armoricain. Tectonics. doi:10.1029/2007TC002115.

Faure M, Monié M, Pin C., Malusky H, Leloix C (2002) Late Visean thermal event in the northern part of the French Massif central: new ${ }^{40} \mathrm{Ar} /{ }^{39} \mathrm{Ar}$ and $\mathrm{Rb}-\mathrm{Sr}$ isotopic constraints on the Hercynian syn-orogenic extension. Int J Earth Sci (Geol Rundsch) 91:53-75

Faure M. (1995) Late orogenic carboniferous extensions in the Variscan French Massif Central. Tectonics 14:132-153.

Floc'h J-P (1983) La série métamorphique du Limousin central, Thèse, Univ. Limoges. Fluck P, Edel J-B, Gagny C, Montigny R, Piqué A, Schneider J-L, Whitechurch H (1987) Le socle vosgien, segment de la chaîne varisque d'Europe : projet Vosges : état des connaissances, propositions d'axes de recherches. Géologie Profonde de la France, Docomuent BRGM 146

Förster HJ (1998) The chemical composition of REE-Y-Th-U-rich accessory minerals in peraluminous granites of the Erzgebirge-Fichtelgebirge region, Germany, Part I: The monazite (Ce)-brabantite solid solution series. Am Min 83:259-272 

questions. Tectonophysics 169:221-228 and Carboniferous magmatism in the Limousin, Massif Central, France: Structural and ${ }^{40} \mathrm{Ar} /{ }^{39} \mathrm{Ar}$ investigations. Tectonics doi:10.1029/2005TC001822. Bresse transform Zone (northern Switzerland and eastern France). Int J Earth Sci 93:207-223, doi. $10.1007 / \mathrm{s} 00531-003-0375-2$

Hames WE, Bowring SA (1994) An empirical evaluation of the argon diffusion in muscovite. Earth Planet Sci Lett 124:161-169. pessure and compositional effects. Geochim Cosmochim Acta 49:2461-2468 ${ }^{40} \mathrm{Ar}$ in muscovite, Geochim Cosmochim Acta 73:1039-1051. Hibbard M.J. (1987) Deformation of incompletely crystallized magma systems: granitic gneisses and their tectonic implications. J Geol 95:543-561 Joly A, Faure M, Martelet G, Chen Y, (2009) Gravity inversion, AMS and 689 geochronological investigations of syntectonic granitic plutons in the southern part of the 690 Variscan French Massif Central. J Struct Geol 31:421-443 
695 Schwarzwald, southwestern Germany. Geol Rdsch 77:25-43

Kruhl JH (1996) Prism- and basal-plane parallel subgrain boundaries in quartz: a

697

698

699

700

701

702

703

704

705

706

707

708

709

710

711

712

713

714

715

716

717

microstructural geothermobarometer. J Metam Geol 14:581-589

Lardeaux JM, Ledru P, Daniel I, Duchêne S (2001) The Variscan Drench Massif

Central - a new addition to the ultra-high pressure metamorphic "club": exhumation processes and geodynamic consequences. Tectonophysics 323:143-167

Launeau P, Robin P-YF (2005) Determination of fabric and strain ellipsoids from

measured sectional ellipses - Implementation and applications. J Struct Geol 27:2223-2233

Ledru P, Lardeaux J-M, Santallier D, Autran A, Quenardel J-M, Floch J-P, Lerouge G,

Maillet N, Marchand J, Ploquin A (1989) Où sont les nappes dans le Massif Central français?

Bull Soc Géol Fr 8:605-618

Ledru P, Courrioux G, Dallain C, Lardeaux J-M, Montel J-M, Vanderhaeghe O, Vitel

G (2001) The Velay dome (French Massif Central): melt generation and granite emplacement during orogenic evolution. Tectonophysics 342:207-237

Leloix C, Faure M, Feybesse J-L (1999) Hercynian polyphase tectonics in north-east French Massif Central: the closure of the Brévenne Devonian-Dinantian rift. Int J Earth Sci $88: 409-421$

Lerouge G, Quenardel J-M (1985) Chronologie des événements tectoniques dans le Nord-Ouest du Massif Central français et le Sud du bassin de Paris du Carbonifère inférieur au Plio-quaternaire. C R Acad Sci, Paris 301:621-626.

Lippolt HJ, Hess JC (1983) Isotopic evidence for the stratigraphic position of the SaarNahe Rotliegend volcanism, I 40Ar/40K and 40Ar/39Ar investigations. N Jb Geol Paläont 713-730. 
Lister GS, Hobbs BE (1980) The simulation of fabric development during plastic

deformation and its application to quartztite: the influence of deformation history. J Struct Geol 2:355-371

Ludwig KR (1999) Users manual for ISOPLOT/EX, version 2. A geochronological toolkit for Microsoft Excel - Berkeley Geochronology Center, Special Publication 1a Ludwig KR (2003) User's manual for Isoplot 3.00. A geochronological toolkit for Microsoft Excel. Berkeley Geochronology Center, 70 p.

Madritsch H, Schmid SM, Fabbri O (2008) Interactions between thin- and thickskinned tectonics at the northwestern front of the Jura fold-and-thrust belt (eastern France). Tectonics. doi:10.1029/2008TC002282.

Mainprice D, Bouchez J-L, Blumenfeld P, Tubia J-M (1986) Dominant c-slip in naturally deformed quartz: implications for dramatic plastic softening at high temperature. Geology 14:819-822

Malavielle J, Guilhot P, Costa S, Lardeaux J-M, Gardien V (1990) Collapse of the thickened Variscan crust in the French Massif Central: Mount Pilat extensional shear zone and St-Etienne upper Carboniferous basin. Tectonophysics 177:139-149

Malavieille J (1987) Kinematics of compressional and extensional ductile shearing deformation in a metamorphic core complex of the northeastern Basin and Range. J Struct Geol 9:541-554

Marteau P (1983) Le bassin permo-carbonifère d'Autun. Stratigraphie, sédimentologie et aspects structuraux. Document BRGM, 64

Mattauer M, Brunel M, Matte P (1988) Failles normales ductiles et grands chevauchements. Une nouvelle analogie entre l'Himalaya et la chaîne hercynienne du Massif central français. C R Acad Sci, Paris 306:671-676 
Matte P (1986) Tectonics and plate tectonics model for the Variscan Belt of Europe.

743 Tectonophysics 126:329-374

Matte P (2001) The Variscan collage and orogeny (480-290 Ma) and the tectonic definition of the Armorica microplate: a review. Terra Nova 13:117-121

Matte P (1991) Accretionary history and crustal evolution of the Variscan Belt in western Europe. Tectonophysics 196:309-337

McClay KR, Norton MG, Coney P, Davis GH (1986) Collapse of the Caledonian orogen and the Old Red Sandstones. Nature 323:147-149

McDougall I, Harrison TM (1999) Geochronology and Thermochronology by the ${ }^{40} \mathrm{Ar} /{ }^{39} \mathrm{Ar}$ method. Oxford University Press, New york, USA

Mehl C, Jolivet L, Lacombe O (2005) From ductile to brittle: evolution and localization of deformation below a crustal detachment (Tinos, Cyclades, Greece) Tectonics doi:4010.1029/2004TC001767

Ménard G, Molnar P (1989) Collapse of a Hercynian Tibetan Plateau into a late Palaeozoic European Basin and Range province. Nature 334:235-237

Monié P, Torres-Roldan RL, Garcia-Casco A (1994) Cooling and exhumation of the western Betic Cordilleras, 40Ar/39Ar thermochronological constraints on a collapsed terrane. Tectonophysics 238:353-379

Monié P, Agard P (2009) Coeval blueschist exhumation along thousands of $\mathrm{km}$ : implications for subduction channel processes, Geochem Geophys Geosyst 10, Q07002, doi:10.1029/2009GC002428.

Montel J-M, Devidal JL, Avignant D (2002) X-ray diffraction study of brabantitemonazite solid solutions. Chem Geol 191:89-104

Moore AC (1970) Descriptive terminology for the textures of rocks in granulite facies terrains. Lithos 3:123-127 
Paris 265:1869-1870

Morre-Biot N (1969) Étude pétrologique du socle cristallin du massif de la Serre, Bull

BRGM (2e série) I 3, 1-16.

Norton MG (1986) Late Caledonide extension in western Norway: a response to extreme crustal thickening. Tectonics 5:195-204

Ogg JG, Ogg G, Gradstein FM (2008) The Concise Geologic Time Scale. Cambridge University Press.

Parrish RR (1990) U-Pb dating of monazite and its application to geological problems.

\section{Can J Earth Sci 27:1431-1450}

Passchier CW, Trouw RAJ (2005). Microtectonics. Springer

Pin C, Dupuy C, Peterlongo J-M (1982) Répartition des terres rares dans les roches volcaniques basiques dévono-dinantiennes du nord-est du Massif central. Bull Soc Géol Fr $7: 669-676$

Pin C, Peucat JJ (1986) Ages des episodes de métamorphisme paléozoïques dans le Massif central et le Massif armoricain. Bull Soc Géol Fr 8:461-469

Pin C (1990) Variscan oceans: ages, origins and geodynamic implications inferred from geochemical and radiometric data. Tectonophysics 177:215-227

Pommier A, Cocherie A, Legendre O (2002) EPMA Dating User's Manual: Age Calculation from Electron Probe Microanalyser Measurements of U-Th-Pb. BRGM Documents, $9 \mathrm{p}$.

Quenardel J-M, Rolin P (1984) Palaeozoic evolution of the Plateau d'Aigurande (NW Massif Central, France). Special Publications 14, Geological Society, London, pp 63-70 
791 Vosges orientales: témoins d'un charriage dans la chaine varisque. C R Acad Sci, Paris $309: 815-821$

Rey P, Burg J-P, Caron J-M (1992) Middle and Late Carboniferous extension in the

\section{4}

Variscan belt: structural and petrological evidence from the Vosges massif (eastern France).

\section{Geodin Acta 5:17-36}

Reynolds SJ, Spencer JE (1985) Evidence for large-scale transport on the Bullard detachment fault, west-central Arizona. Geology 13:353-356

Roig J-Y, Faure M (2000) La tectonique cisaillante polyphasée du S. Limousin (Massif central français) et son interprétation dans un modèle d'évolution polycyclique de la chaîne hercynienne. Bull Soc Géol Fr 171:295-307

Rolin P, Colchen M (2001) Carte structurale du socle Varisque Vendée-Seuil du Poitou-Limousin. Géologie de la France, 1-2:3-6

Rolin P, Stussi J-M (1991) Décrochements intracrustaux et intrusions granitiques carbonifères dans le Morvan (Massif central français). Bull Soc Géol Fr 162:839-859

Ruffet G, Féraud G, Amouric M (1991) Comparison of ${ }^{40} \mathrm{Ar}-{ }^{39} \mathrm{Ar}$ conventional and laser dating of biotites from the North Trégor Batholith. Geochim Cosmochim Acta 55:16751688.

Samson SD, Alexander ECJ (1987) Calibration of the interlaboratory ${ }^{40} \mathrm{Ar}-{ }^{39} \mathrm{Ar}$ dating standard, MMhb-1. Chem Geol 66:27-34

Schulmann K, Schaltegger U, Jezek J, Thompson A, Edel J-B (2002) Rapid burial and exhumation during orogeny: thickening and synconvergent exhumation of thermally weakened and thinned crust (Variscan orogen in western Europe). Am J Sci 302:856-879 Simpson C, Wintsch RP (1989) Evidence for deformation-induced K-feldspar replacement by myrmekite. J Metamorph Geol 7:261-275 
816 a "natural laboratory" for crystal plastic deformation of quartz over a temperature range from 817250 to $750{ }^{\circ} \mathrm{C}$. J Struct Geol 24:1861-1884

Talbot J-Y, Martelet G, Courrioux G, Chen Y, Faure M (2004) Emplacement in an extensional setting of the Mont Lozère-Borne granitic complex (SE France) inferred from comprehensive AMS, structural and gravity studies. J Struct Geol 26:11-28 Variscan orogen. J Struct Geol 27:1610-1629

Turner G, Cadogan PH (1974) Possible effects of ${ }^{39} \mathrm{Ar}$ recoil in ${ }^{40} \mathrm{Ar}-{ }^{39} \mathrm{Ar}$ dating. Proceedings of the Fifth Lunar Science Conference 2:1601-1615 the Upper Rhine Graben - Jura Mountains junction. Swiss Journal of Geosciences 100:293-

Vallé B, Courel L, Gélard J-P (1988) Les marqueurs de la tectonique synsédimenatire 830 et syndiagénétique dans le bassin stéphanien à régime cisaillant de Blanzy-Montceau (Massif 831 Central, France). Bull Soc Géol Fr 8, IV 4:529-540 Wickert F, Eisbacher GH (1988) Two-sided Variscan thrust tectonics in the Vosges 833 Mountains, northeastern France. Geodin Acta 2:101-120 terrestrial minerals with a continuous laser. Geophys Res Lett 8:1136-1138. 
Figure captions

Figure 1: Geological map of the NW French Massif Central and the Vosges (modified after Fluck et al., 1987; Coromina and Fabbri, 2004; Faure et al. 2008). Location of the Autun and La Serre areas are also represented. AU: Autun Basin; EP: Epinac Basin; LC: Le Creusot Basin; SH: Sillon Houiller; MCSZ: La Marche-Combrailles Shear Zone; ASZ: Autun Shear Zone; SMF: La Serre Median Fault ; SMMF: Sainte-Marie-aux-Mines Fault.

Figure 2: a): Simplifed geological map of the Autun area; b) cross section of the Autun area c) stereoplots of foliations and lineations observed in the granite and along the mylonitic zone.

Figure 3: a): Simplifed geological map of the la Serre area (modified after Coromina and Fabbri, 2004); b) cross section of the La Serre area c) stereoplots of foliations and lineations observed in the granite and in the mylonite.

Figure 4: Microstructure of the granite and the mylonite of the Autun and La Serre shear zones. Bt: biotite; Ms: muscovite; Ort: orthoclase; Plg: plagioclase; Qz: quartz. a: undeformed, with weak preferred orientation Autun leucogranite, b: Shear bands (yellow) cutting primary magmatic foliation (red) in Autun mylonite, c: chessboard texture in quartz showing prismatic subgrains in the La Serre granite, d: myrmekite indicating syn-magmatic deformation of the Autun granite, e: dynamically recrystallized quartz ribbons in the La Serre mylonite, f: mantle porphyroclasts of a K-feldspar in Autun mylonite, with a o-type shear criterion, g: muscovite micafish in shear bands in Autun mylonite, h: detail of elongated newly formed quartz grains developed by dynamic recrystallization in Autun mylonite.

Figure 5: 3D fabric of Autun granites and mylonites deduced from preferred orientation of mica in three perpendicular planes. AU19 and AU16 are granites, AU20 and AU02 are mylonites. Manual (Man.) and automatic (Auto.) measurements of the orientation 
864 of elongated micas are given in rose diagrams with $10^{\circ}$ equal intervals (see text for more

865

866

867

868

869

870

871

872

873

874

875

876

877

878

879

880

881

882

883

884

885

886 explanation).

Figure 6: Universal Stage measurements of the lattice preferred orientation of the quartz c-axes of Autun granite (a) and La Serre granite (b). Schmidt stereographic net (lower hemisphere) was used for projecting quartz c-axes. Contours are 1, 2, 3, 4, 5, 6, 7, 8\% for 1\% area. For each area, the mylonite shows a well-developed quartz c-axis maximum representative of crystal plasticity. The magmatic fabric in granite presents a high-temperature preferred orientation.

Figure 7: a: Photomicrograph of a monazite grain enclosed in biotite in the La Serre granite. Ap: Apatite; Bt: biotite; Mzt: monazite; Ort: orthoclase; Plg: plagioclase; Qz: quartz. b, $\mathrm{c}$ and $\mathrm{d}$ ) : Isochron $\mathrm{Th} / \mathrm{Pb}$ vs. U/Pb diagrams of samples AU16, AU26 SE03. For each rock, examples of Back-Scattered Electron Scan Electron Microscope images of analyzed monazite grains are shown. See sample locations in Fig. 2 and Fig. 3.

Figure 8: ${ }^{40} \mathrm{Ar} /{ }^{39} \mathrm{Ar}$ age spectra of Autun granite and mylonite (a to e)) and La Serre mylonites (f). See location in Fig. 2 and Fig. 3.

Figure 9: Simplified basement map of northeastern France. Deep Carboniferous basins and faults are modified after Ustaszewski et al. (2007) and hidden leucogranites are inferred from the gravimetric map of Edel (2008).

Figure 10: Synoptic chart of new geochronological data, showing that a ca. 15 myrs time gap separates the pluton emplacement and the ductile deformation. Two possible cooling paths of Autun and La Serre plutons are depicted.

Table $1{ }^{40} \mathrm{Ar} /{ }^{39} \mathrm{Ar}$ analytic data. 


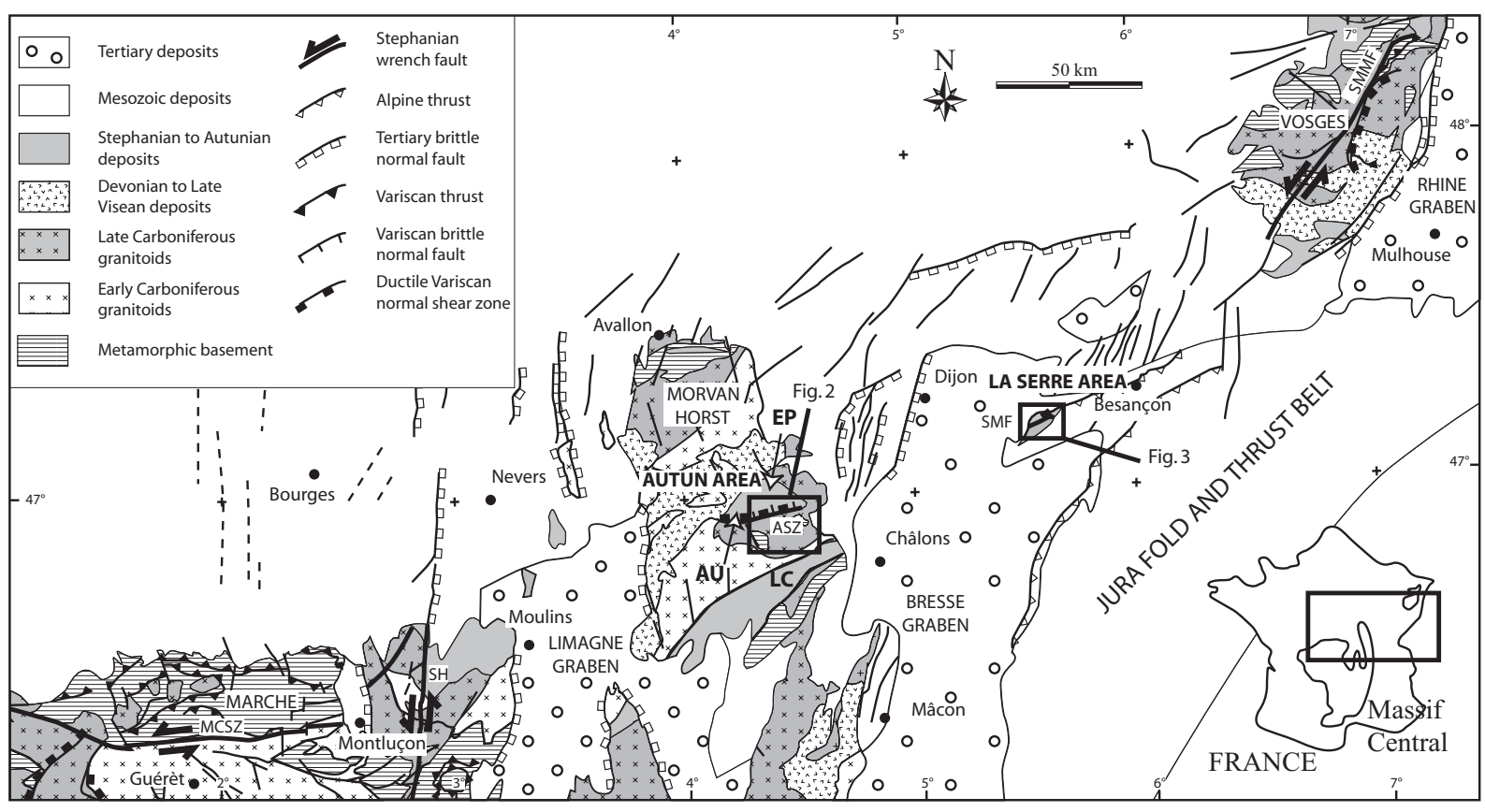

Figure 1 


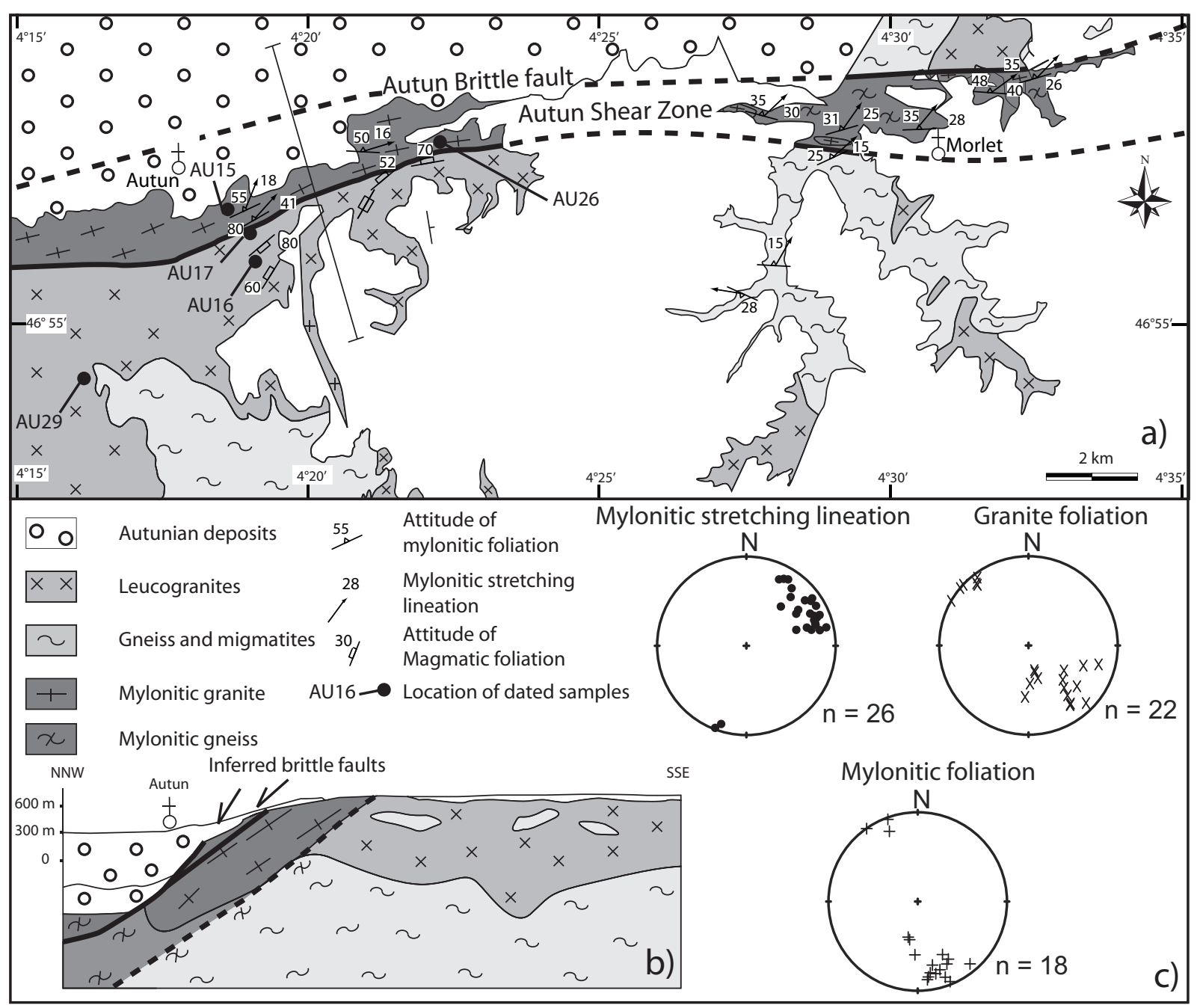

Figure 2 


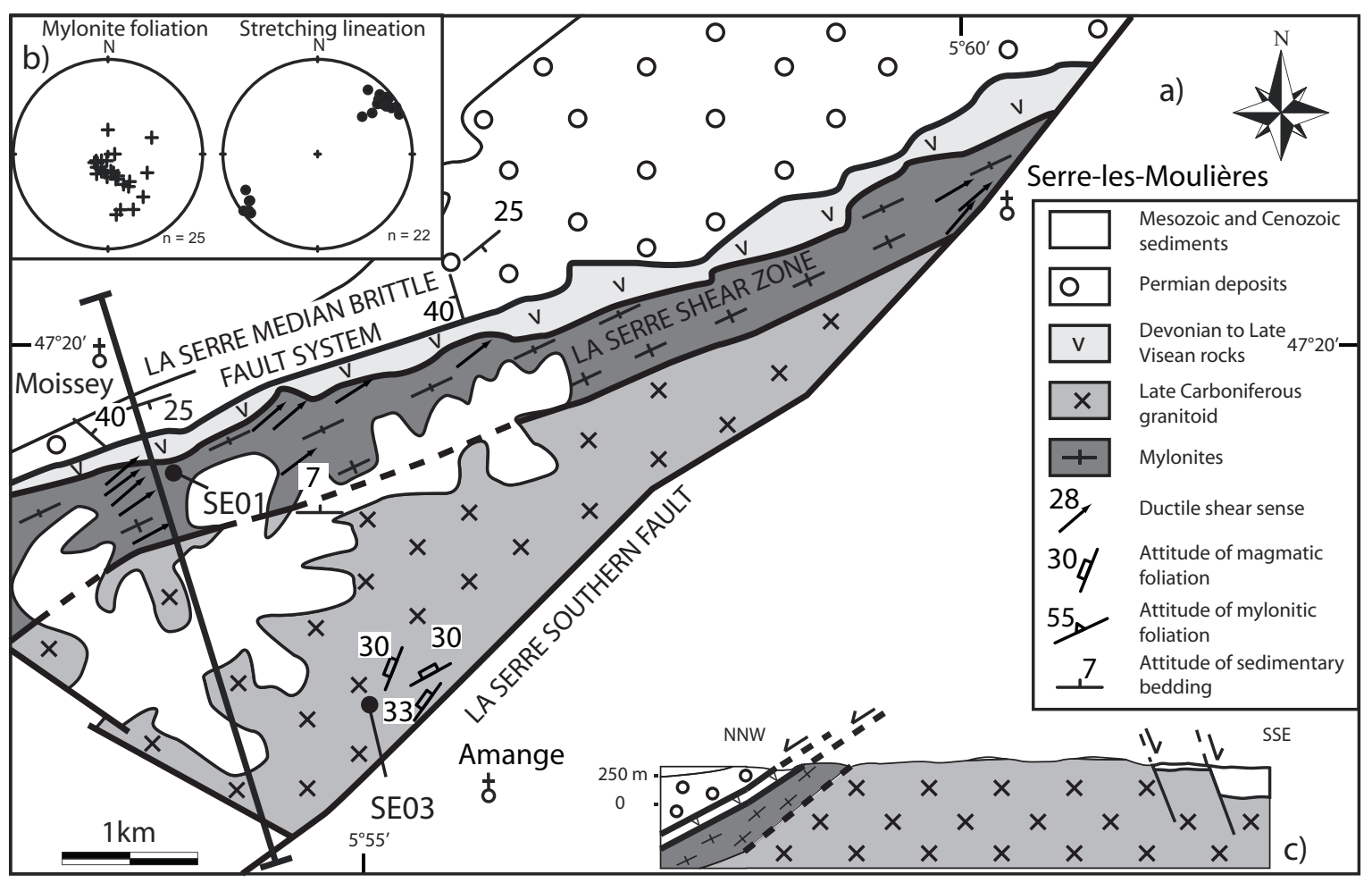

Figure 3 


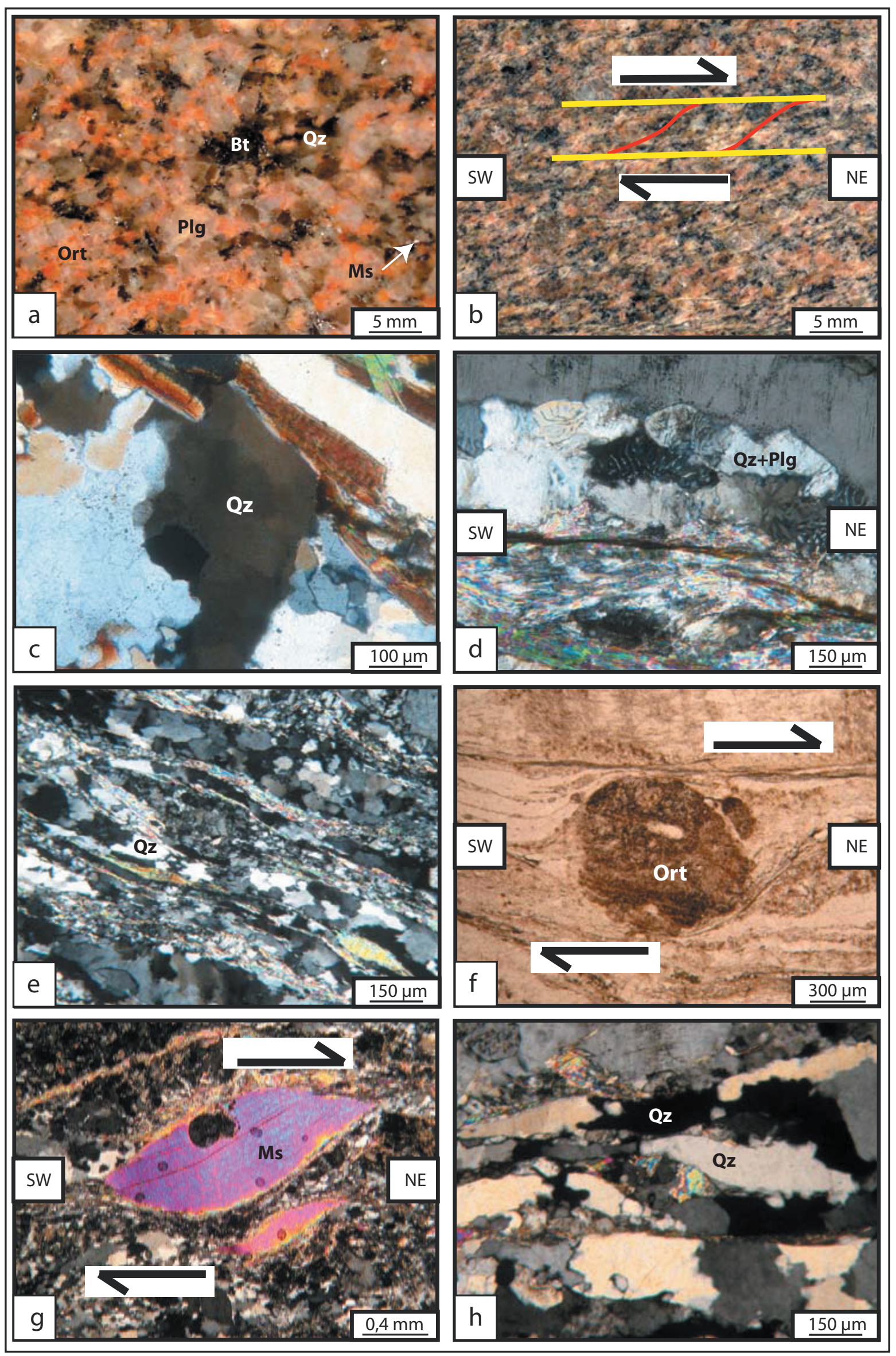




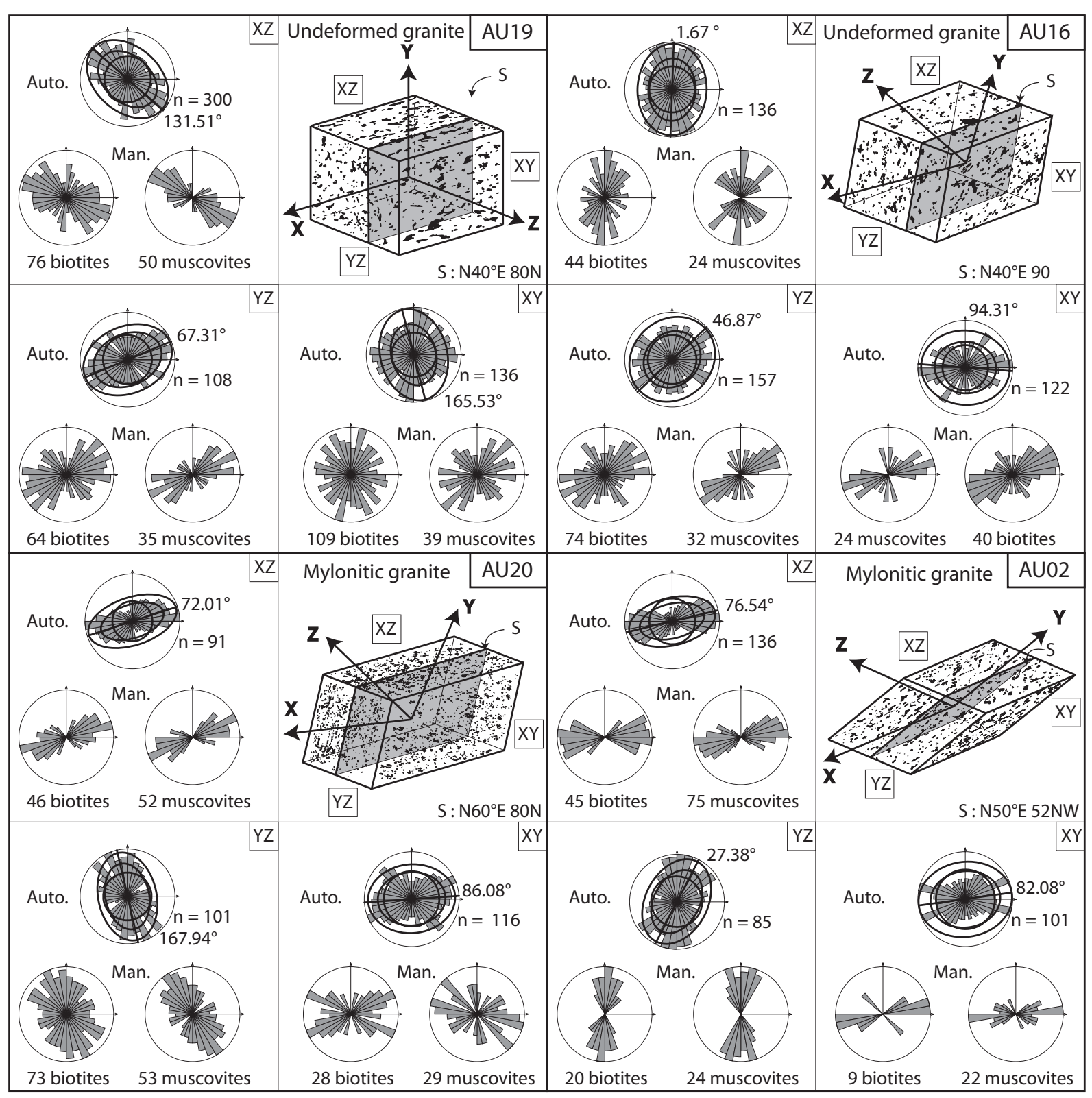




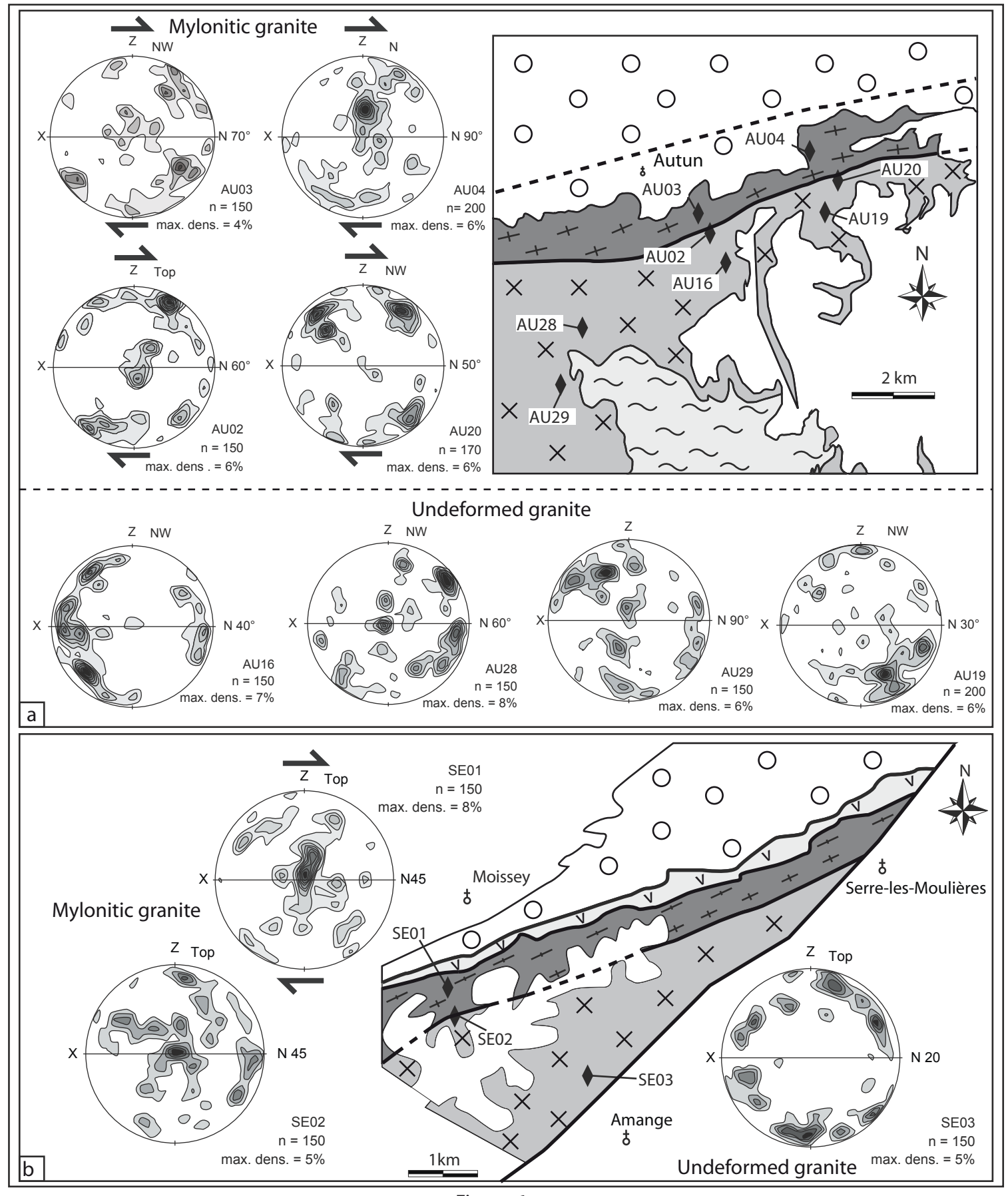

Figure 6 


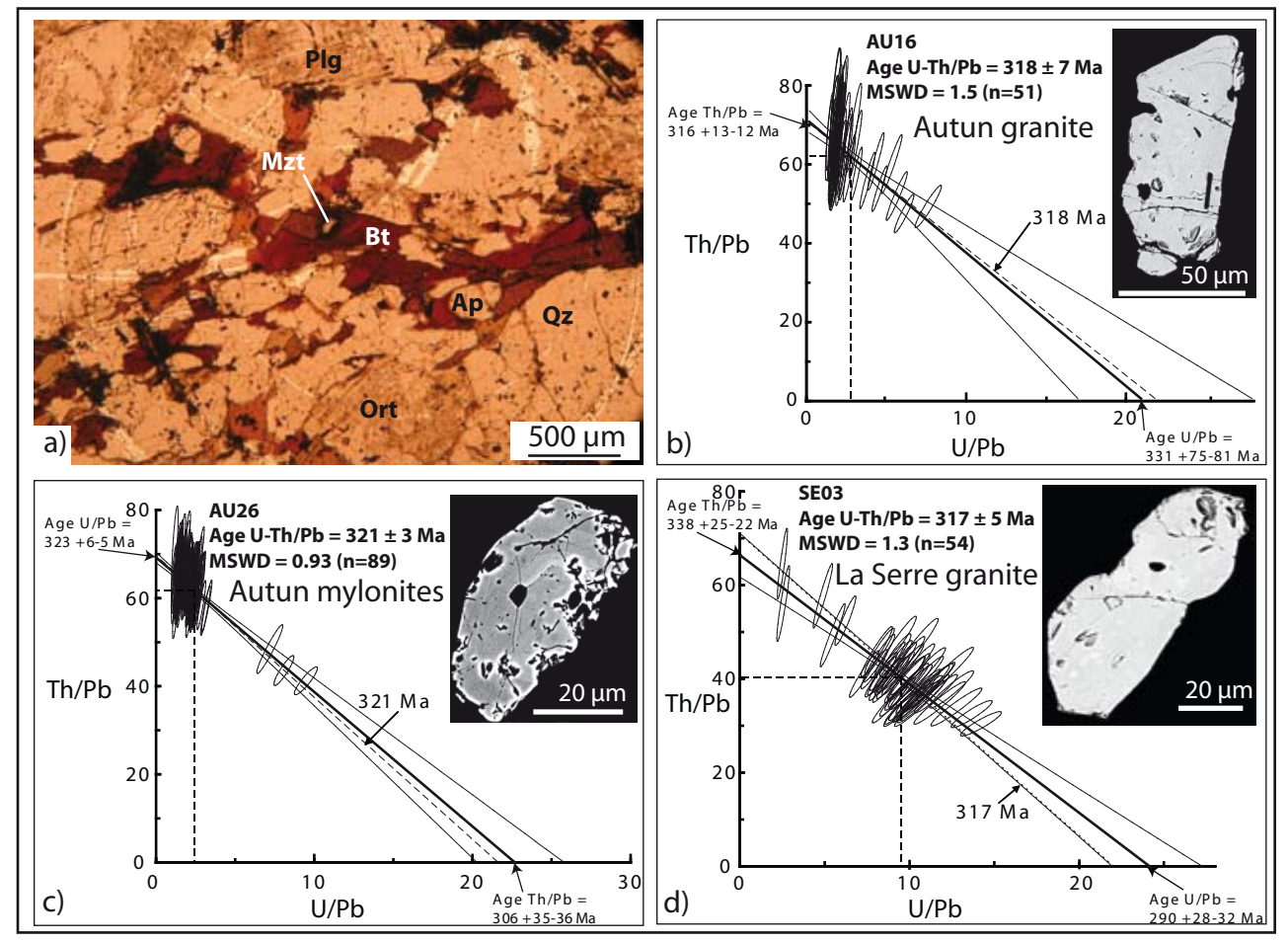

Figure 7 

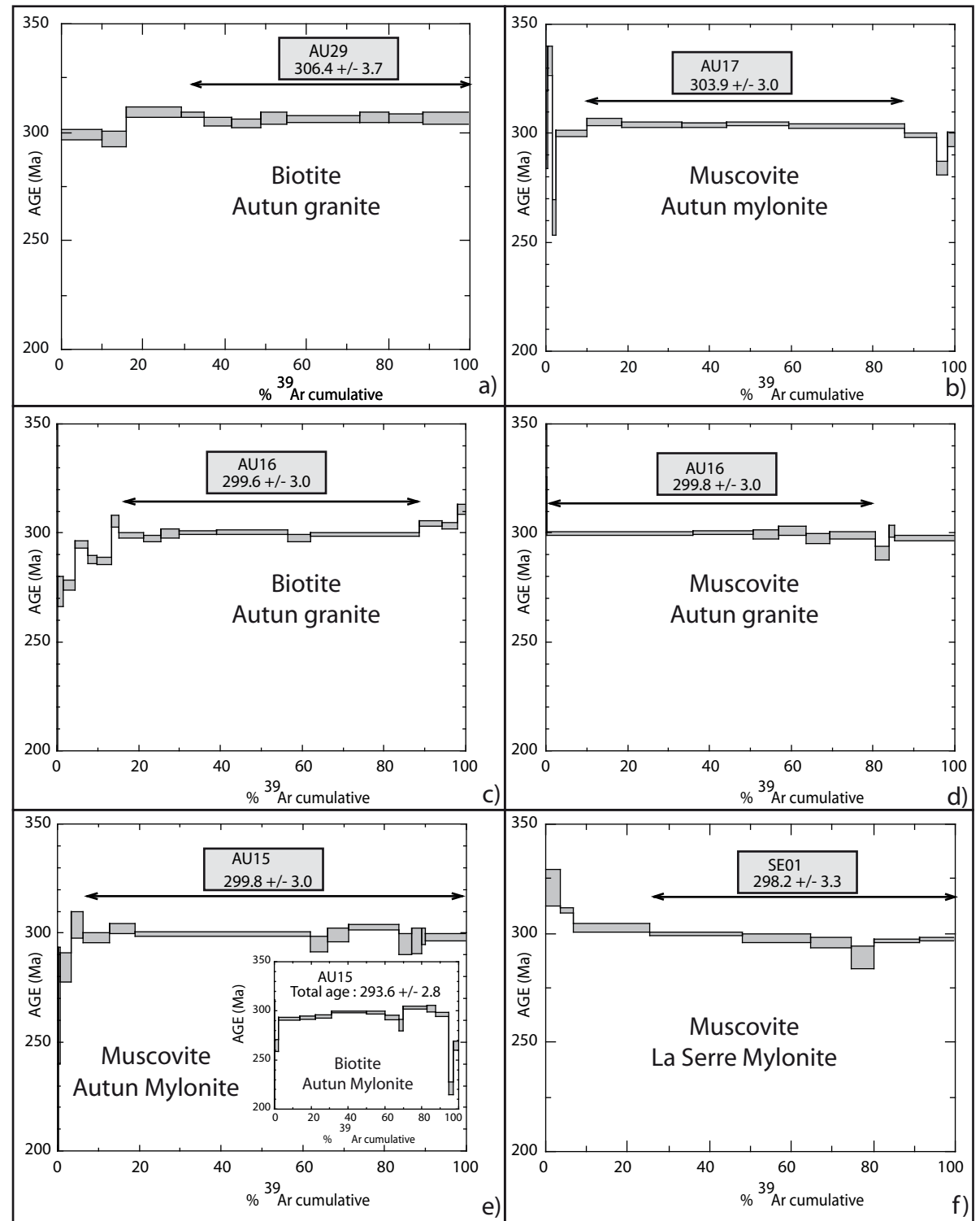

Figure 8 


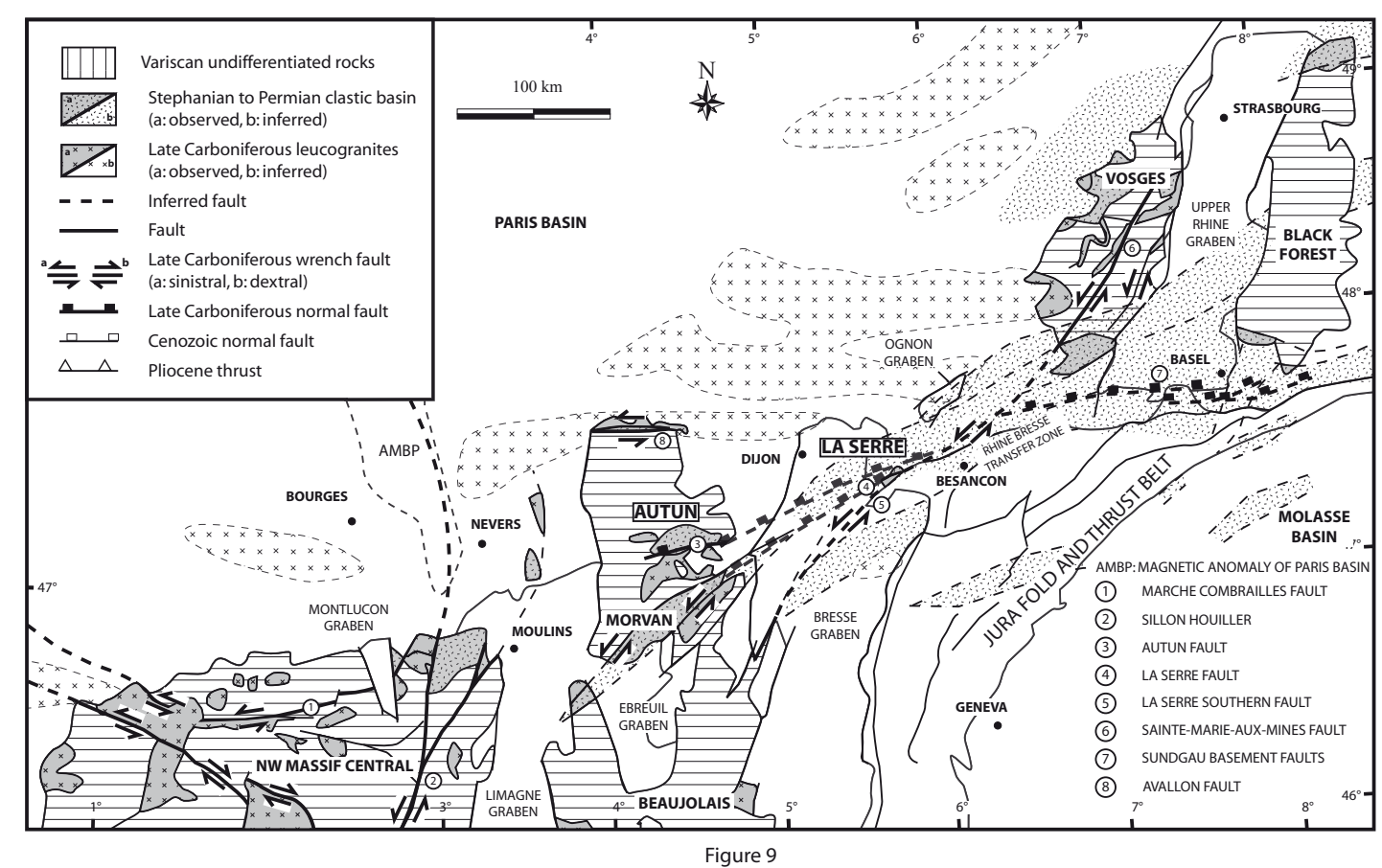

903

904 


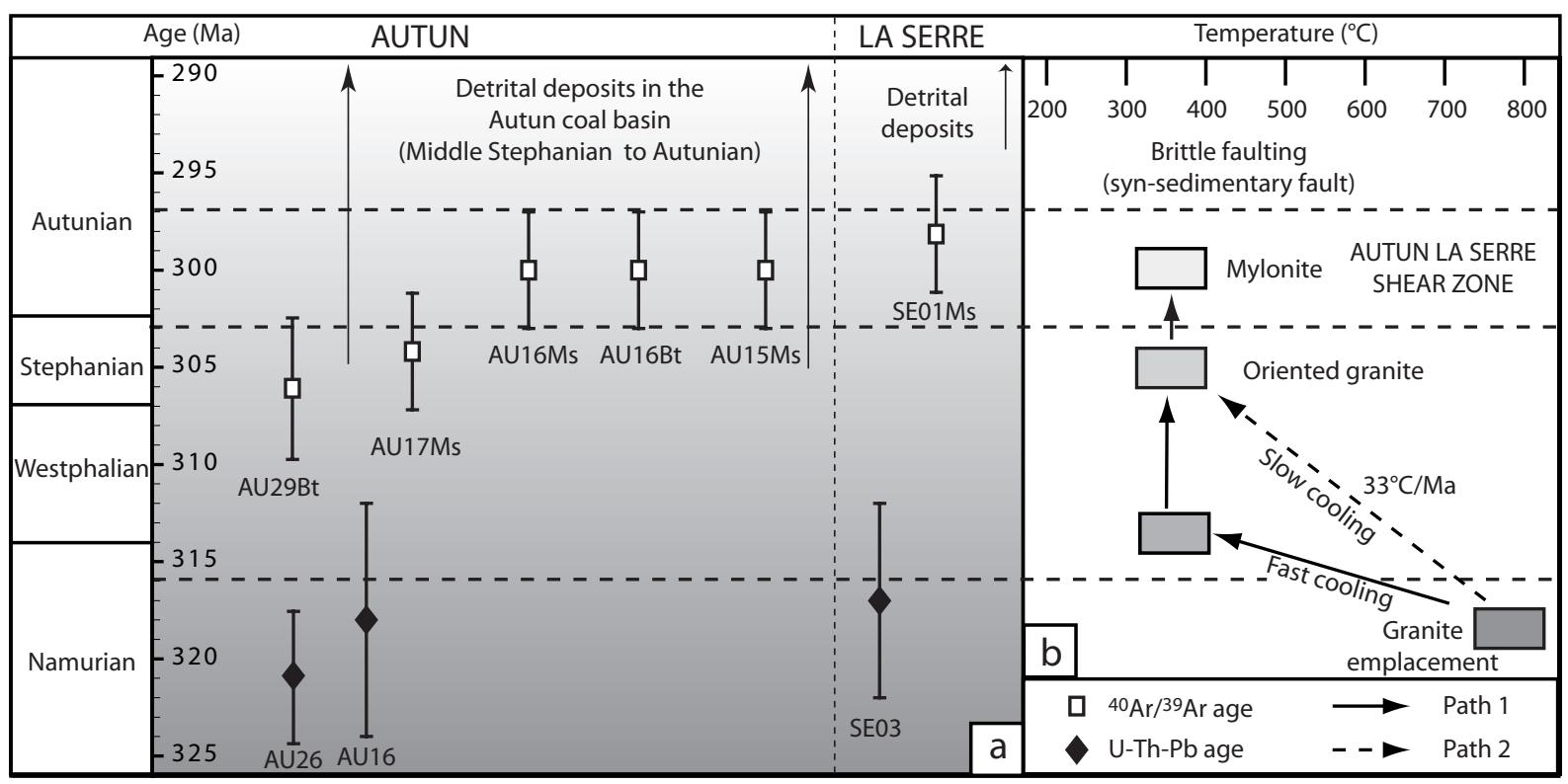




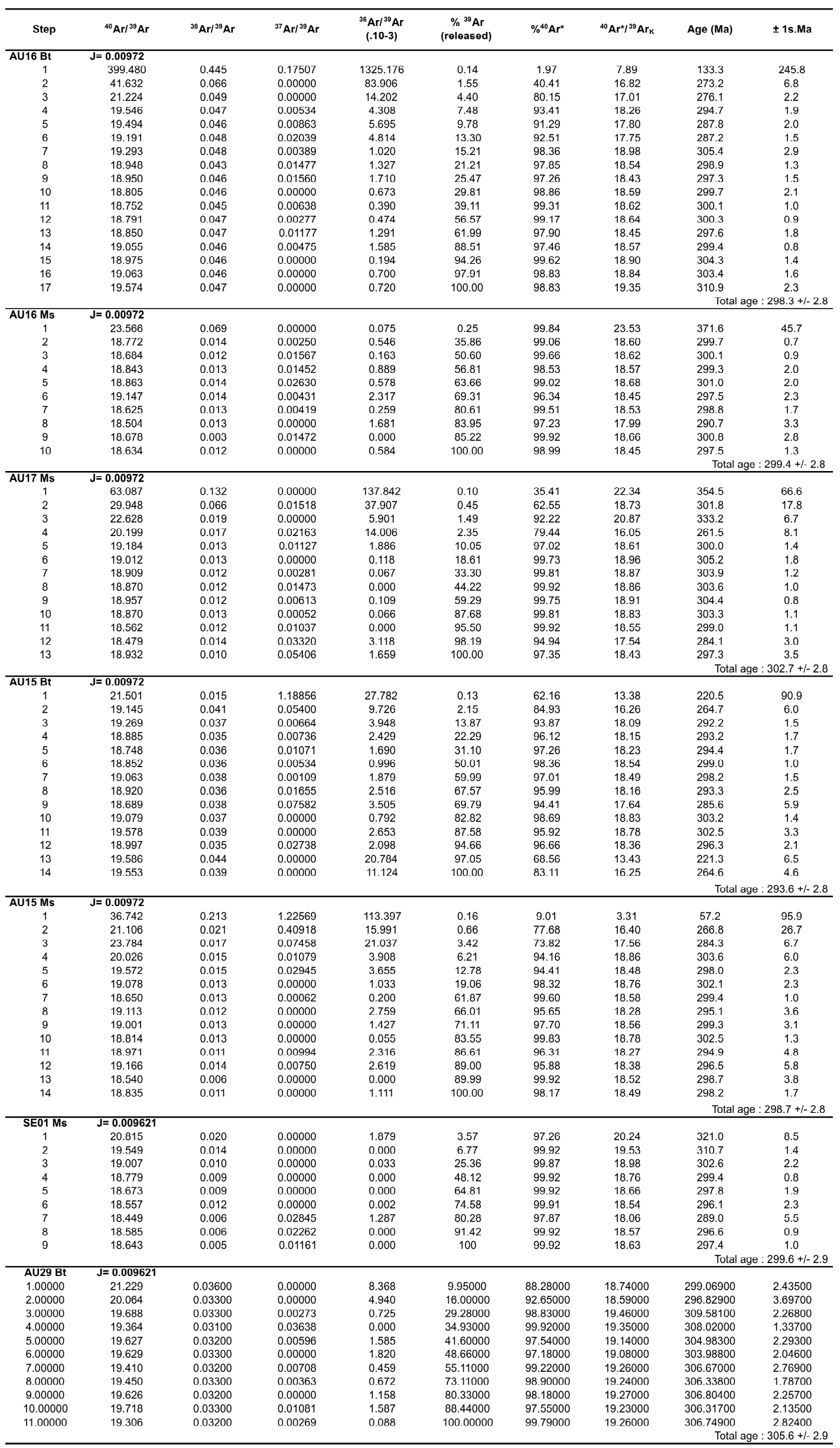

